ANDREW HYNES SERIES:

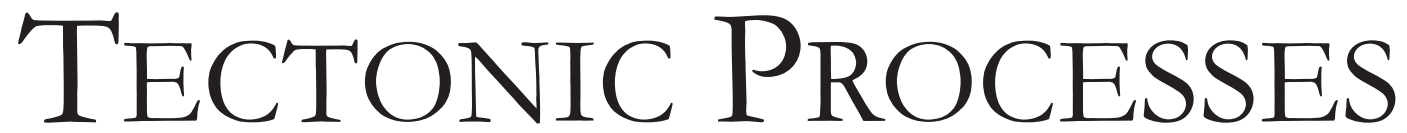

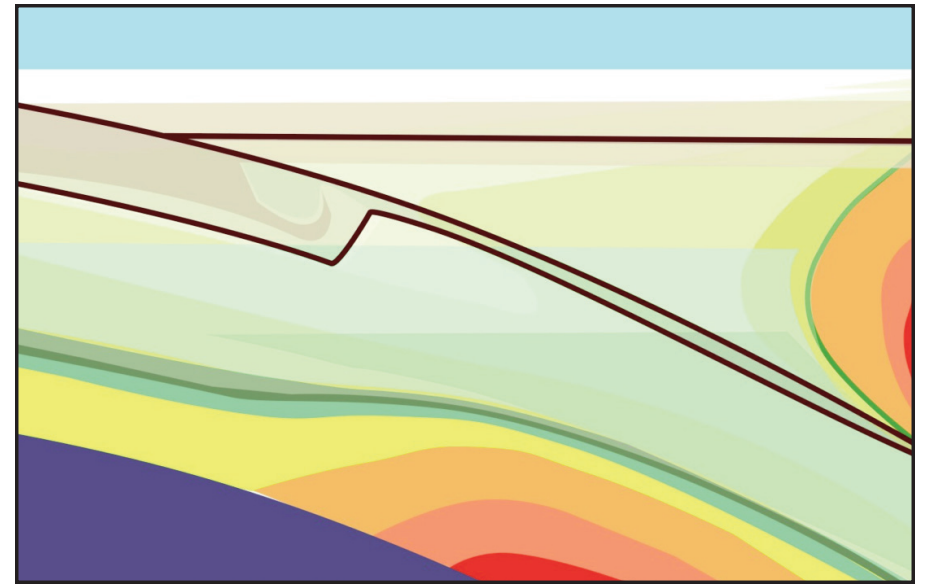

\section{Lithotectonic Framework of the Core Zone, Southeastern Churchill Province, Canada}

David Corrigan ${ }^{1}$, Natasha Wodicka ${ }^{1}$, Christopher

McFarlane $^{2}$, Isabelle Lafrance, Deanne van Rooyen ${ }^{4}$, Daniel Bandyayera ${ }^{3}$, and Carl Bilodeau ${ }^{3}$

${ }^{1}$ Geological Survey of Canada

601 Booth Street, Ottawa, Ontario, Canada, K1 A OE8

E-mail:david.corrigan@_canada.ca

${ }^{2}$ Department of Earth Sciences

University of New Brunswick

2 Bailey Drive, Fredericton, New Brunswick, Canada, E3B 5 A3

${ }^{3}$ Ministère de L'Énergie et des Ressources naturelles

5700, $4^{\text {ime }}$ Avenue Ouest, Ville de Québec

Québec, Canada, G1H 6R1

${ }^{4}$ Department of Mathematics, Physics and Geology

Cape Breton University

1250 Grand Lake Road, Sydney, Nova Scotia, Canada, B1P 6L2

\section{SUMMARY}

The Core Zone, a broad region located between the Superior and North Atlantic cratons and predominantly underlain by Archean gneiss and granitoid rocks, remained until recently one of the less well known parts of the Canadian Shield. Pre- viously thought to form part of the Archean Rae Craton, and later referred to as the Southeastern Churchill Province, it has been regarded as an ancient continental block trapped between the Paleoproterozoic Torngat and New Quebec orogens, with its relationships to the adjacent Superior and North Atlantic cratons remaining unresolved. The geochronological data presented herein suggest that the Archean evolution of the Core Zone was distinct from that in both the Superior and North Atlantic (Nain) cratons. Moreover, the Core Zone itself consists of at least three distinct lithotectonic entities with different evolutions, referred to herein as the George River, Mistinibi-Raude and Falcoz River blocks, that are separated by steeply-dipping, crustal-scale shear zones interpreted as paleosutures. Specifically, the George River Block consists of ca. $2.70 \mathrm{Ga}$ supracrustal rocks and associated ca. 2.70-2.57 Ga intrusions. The Mistinibi-Raude Block consists of remnants of a ca. 2.37 Ga volcanic arc intruded by a ca. $2.32 \mathrm{Ga}$ arc plutonic suite (Pallatin) and penecontemporaneous alkali plutons (Pelland and Nekuashu suites). It also hosts a coarse clastic cover sequence (the Hutte Sauvage Group) which contains detrital zircons provided from locally-derived, ca. 2.57-2.50 $\mathrm{Ga}, 2.37-2.32 \mathrm{Ga}$, and 2.10-2.08 Ga sources, with the youngest concordant grain dated at $1987 \pm 7 \mathrm{Ma}$. The Falcoz River Block consists of ca. 2.89-2.80 Ga orthogneiss intruded by ca. 2.74-2.70 granite, tonalite, and granodiorite. At the western margin of the Core Zone, the George River Block and Kuujjuaq Domain may have been proximal by ca. $1.84 \mathrm{Ga}$ as both appear to have been sutured by the 1.84-1.82 Ga De Pas Batholith, whereas at its eastern margin, the determination of metamorphic ages of ca. 1.85 to $1.80 \mathrm{Ga}$ in the Falcoz River Block suggests protracted interaction with the adjacent Lac Lomier Complex during their amalgamation and suturing, but with a younger, 'New Quebec' overprint as well. The three crustal blocks forming the Core Zone add to a growing list of 'exotic' Archean to earliest Paleoproterozoic microcontinents and crustal slices that extend around the Superior Craton from the Grenville Front through Hudson Strait, across Hudson Bay and into Manitoba and Saskatchewan, in what was the Manikewan Ocean realm, which closed between ca. 1.83-1.80 Ga during the formation of supercontinent Nuna.

\section{RÉSUMÉ}

La Zone noyau, une vaste région située entre les cratons du Supérieur et de l'Atlantique Nord et reposant principalement

Geoscience Canada, v. 45, https://doi.org/10.12789/geocanj.2018.45.128 pages 1-24 $\quad$ C 2018 GAC/AGC® 
sur des gneiss archéens et des roches granitiques, est demeurée jusqu'à récemment l'une des parties les moins bien connues du Bouclier canadien. Considérée auparavant comme faisant partie du craton archéen de Rae, puis comme la portion sud-est de la Province de Churchill, on l'a perçue comme un ancien bloc continental piégé entre les orogènes paléoprotérozoïques des Torngat et du Nouveau-Québec, ses relations avec les cratons supérieurs adjacents et de l'Atlantique Nord demeurant nébuleuses. Les données géochronologiques présentées ici permettent de penser que l'évolution archéenne de la Zone noyau a été différente de celle des cratons du Supérieur et de l'Atlantique Nord (Nain). De plus, la Zone noyau elle-même se compose d'au moins trois entités lithotectoniques distinctes avec des évolutions différentes, appelées ici les blocs de la rivière George, de Mistinibi-Raude et de la rivière Falcoz, lesquels sont séparées par des zones de cisaillement crustales à forte inclinaison, conçues comme des paléosutures. Plus précisément, le bloc de la rivière George est constitué de roches supracrustales d'env. 2,70 Ga, et d'intrusions connexes d'env. 2,70-2,57 Ga. Le bloc Mistinibi-Raude est constitué de vestiges d'un arc volcanique d'env. 2,37 Ga, recoupé par une suite plutonique d'arc d'env. 2,32 Ga (Pallatin) et de plutons alcalins péné-contemporains (suites Pelland et Nekuashu). Il contient également une séquence de couverture clastique grossière (le groupe Hutte Sauvage) renfermant des zircons détritiques de sources locales, âgés d'env. 2,57-2,50 Ga, 2,37-2,32 Ga et 2,10-2,08 Ga, le grain concordant le plus jeune étant âgé de $1987 \pm 7$ Ma. Le bloc de la rivière Falcoz est formé d'un orthogneiss âgé d'env. 2,89-2,80 Ga, recoupé par des intrusions de granite, tonalite et granodiorite âgées d'env. 2,74-2,70 Ga. À la marge ouest de la Zone noyau, le bloc de la rivière George et du domaine de Kuujjuaq peuvent avoir été proximaux il y a 1,84 Ga env., car les deux semblent avoir été suturés par le batholithe De Pas il y a environ 1,84-1,82 Ga, alors qu'à sa marge est, la détermination des datations métamorphiques de 1,85 à 1,80 $\mathrm{Ga}$ dans le bloc de la rivière $\mathrm{Falcoz}$ suggère une interaction prolongée avec le complexe adjacent du lac Lomier durant leur amalgamation et leur suture, mais affecté aussi d'une surimpression "Nouveau Québec » plus jeune. Les trois blocs crustaux formant la Zone noyau s'ajoutent à une liste croissante de micro-continents et d'écailles crustales " exotiques » archéennes à paléoprotérozoïques très précoces qui s'étalent autour du craton Supérieur depuis le front de Grenville jusqu'au Manitoba, à travers le détroit d'Hudson, la baie d'Hudson jusque dans le Manitoba et la Saskatchewan, là où s'étendait l'océan Manikewan, lequel s'est refermé il y a environ 1,83-1,80 Ga, pendant la formation du supercontinent Nuna.

Traduit par le Traducteur

\section{INTRODUCTION}

Much of the crustal growth of the interior of Laurentia (North American Precambrian continent) occurred by tectonic and magmatic accretion during the Paleoproterozoic, between ca. 2.0 and $1.8 \mathrm{Ga}$ (Fig. 1). The resulting landmass consists of a collage of large, stable Archean cratons (Slave, Superior and North Atlantic), bound together by mobile belts (mostly com- ponents of the Churchill Province) that are composed of a mosaic of variably reactivated Archean crustal blocks (also referred to as 'cratons' or 'provinces') and microcontinents as well as juvenile Proterozoic crust, magmatic arcs, and intracratonic sedimentary basins (Hoffman 1988, 1990; Lewry and Collerson 1990; Rainbird 2004; St-Onge et al. 2006; Whitmeyer and Karlstrom 2007; Corrigan et al. 2009). The Churchill Province has been historically separated into a western part (Western Churchill Province) west of Hudson Bay, a central part situated north of Hudson Strait, and a southeastern arm (Southeastern Churchill Province), lying between the Superior and North Atlantic cratons south of Ungava Bay (Hoffman 1990). Earlier syntheses suggested that most of the Churchill Province was underlain by two distinct Archean crustal blocks termed the Rae and Hearne 'provinces' (e.g. Hoffman 1988), whereas subsequent models based on a large geochronological database and an interpretation of regional aeromagnetic lineaments permitted the identification of a collage of other distinct Archean to earliest-Paleoproterozoic crustal blocks confined within the mobile belts, including the Sask 'craton,' Sugluk 'block,' Meta-Incognita 'micro-continent' and Core Zone (Chiarenzelli et al. 1998; James and Dunning 2000; Hajnal et al. 2005; St-Onge et al. 2006; Corrigan et al. 2009). The Churchill Province is interpreted as the more or less contiguous area of the collage described above that was thermally and structurally affected by terminal collision with the Superior Craton during the interval 1.83 to $1.80 \mathrm{Ga}$ (Lewry and Collerson 1990; Corrigan et al. 2009).

This paper presents a new synthesis of the Core Zone (Fig. 2), one of the Archean blocks or microcontinents forming the Churchill Province collage, and provides some speculations on its relationship with the bounding New Quebec and Torngat orogens. The results highlighted herein stem from recent 1:100,000-scale bedrock mapping in the Core Zone, led by the Ministère de l'énergie et des ressources naturelles du Québec (Hammouche et al. 2011; Simard et al. 2013; Lafrance et al. 2014), as well as thematic mapping by the Geological Survey of Canada under the auspices of the Geo-mapping for Energy and Minerals (GEM) program (Corrigan et al. 2015, 2016; Sanborn-Barrie et al. 2015; Sanborn-Barrie 2016). We present a synthesis of previous work and new bedrock geology observations, as well as $\mathrm{U}-\mathrm{Pb}$ zircon ages that provide constraints on the crustal evolution of the Core Zone and its role in the tectonic evolution of the Churchill Province. Earlier work by Wardle and van Kranendonk (1996), Girard (1990a, b, c), James and Dunning (2000) and Simard et al. (2013), among others, has recognized the existence of a major network of sub-parallel to anastomosing shear zones separating elongate to lens-shaped blocks along the north-south extent of the Core Zone. We provide arguments suggesting that the Core Zone comprises at least three distinct Archean to earliest-Paleoproterozoic crustal blocks that are separated by sutures. We speculate on the crustal evolution of these crustal blocks, the timing of their amalgamation, their relationship with the flanking Superior and North Atlantic cratons, as well as their possible correlatives elsewhere in the Churchill Province. 


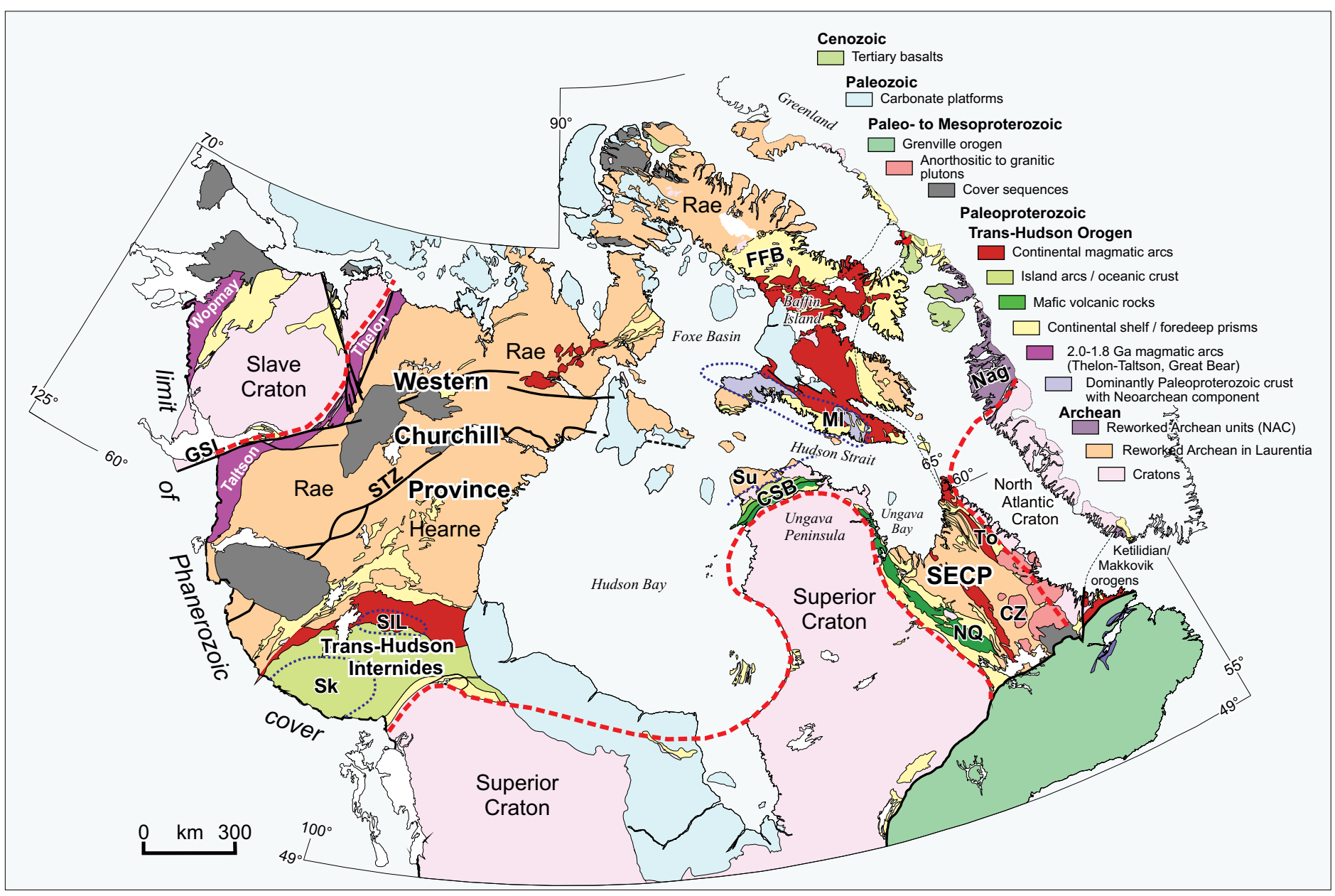

Figure 1. Simplified bedrock geology map of Laurentia. Abbreviations: CSB, Cape Smith Belt; CZ, Core Zone; FFB, Foxe Fold Belt; MI, Meta-Incognita microcontinent; Nag, Nagssugtoqidian Orogeny; NQ, New Quebec Orogen; SECP, Southeastern Churchill Province; SIL, Southern Indian Lake; Sk, Sask Craton (showing interpreted outline at MOHO); Su, Sugluk Block; To, Torngats Orogen. Map modified after Hoffman (1990).

\section{REGIONAL SETTING}

The Core Zone (Fig. 2) forms an 500-km-long by 200-kmwide crustal domain that is situated in the central part of the Southeastern Churchill Province. It has been interpreted as an elongate sliver of Archean continental crust (ribbon continent) that was accreted between the colliding Superior and North Atlantic cratons during the Paleoproterozoic (James et al. 1996; James and Dunning 2000; Wardle et al. 2002). It is flanked on its western side by the ca. 1.83-1.80 Ga New Quebec Orogen (Hoffman 1988; Perreault and Hynes 1990; Moorhead and Hynes 1990), and on its eastern side by the ca. 1.87-1.86 Ga Torngat Orogen (Wardle et al. 2002 and references therein). The extent to which it is affected by tectonism related to either of these orogens remains unclear, although the 'New Quebec' overprint appears to be more widespread. The earliest systematic mapping of the Core Zone was performed during 'Operation Torngat,' a helicopter-supported survey conducted by the Geological Survey of Canada that was completed in the late 1960s and resulted in the publication of a series of 1:250,000-scale bedrock maps (Taylor 1979). Lithological units on these maps consist mostly of Archean orthogneiss with minor paragneiss and plutonic rocks. Detailed mapping in the south-central part of the Core Zone by Girard (1990a, b) and van der Leeden (1994) highlighted the presence of supracrustal and plutonic rocks of low- to medium-metamorphic grade in the central part of the Core Zone (MistinibiRaude Block), with the supracrustal rocks hosting a plutonic unit that yielded a U-Pb zircon age of ca. $2.33 \mathrm{Ga}$ (Girard 1990a). In addition, throughout the Core Zone, Girard (1990b) recognized the presence and significance of major, orogenparallel ductile shear zones that separated distinct crustal blocks. Subsequently, James et al. (2003) and Hammouche et al. (2011) completed regional mapping and U-Pb geochronology on key protoliths in the southern part of the Core Zone north of Smallwood Reservoir. In the same area, Nunn et al. (1990) had previously recognized the presence of ca. 2.68-2.67 Ga tonalite and mafic volcanic rocks having minimal Proterozoic overprint, collectively suggesting variable degrees of tectonothermal overprint throughout the Core Zone, ranging from granulite to sub-greenschist facies. Bedrock geological mapping along the northern extents of the Core Zone was performed by Verpaelst et al. (2000) and Simard et al. (2013).

The Core Zone has historically been interpreted to encompass the entire span of Archean rocks exposed between Pale- 


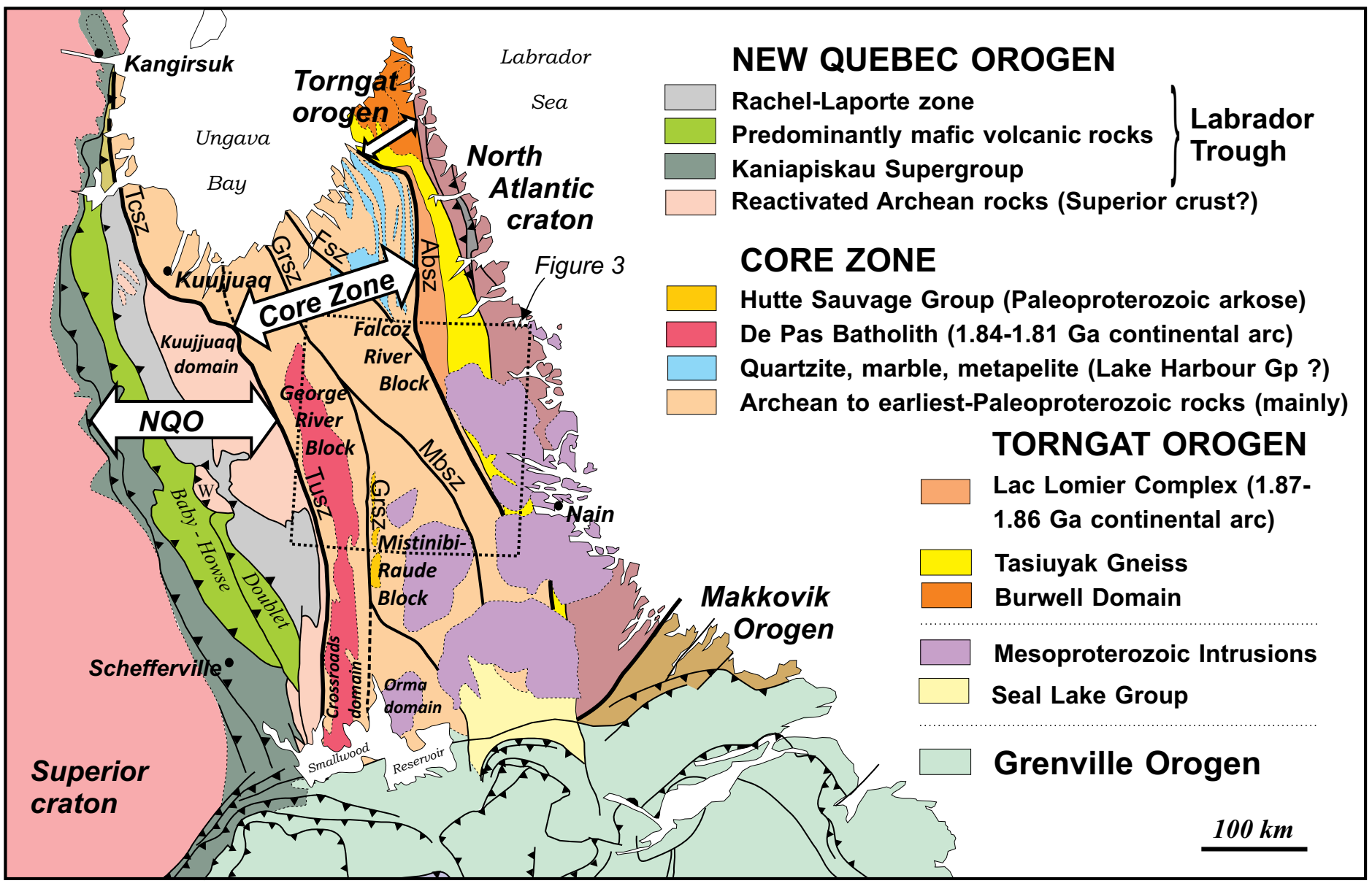

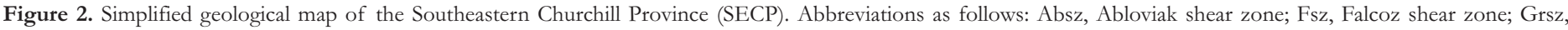

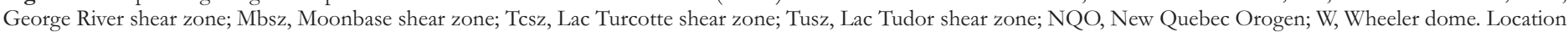
of Figure 3 shown in box. Modified after James and Dunning (2000).

oproterozoic rocks of the Labrador Trough to the west and the Lac Lomier domain to the east (Wardle and Van Kranendonk 1996). However, there are inherent uncertainties regarding this approach. Specifically, these concern the origin of Archean rocks exposed between the eastern edge of the Labrador Trough and the Lac Tudor shear zone (Fig. 2), and their potential affinity with the Superior Craton. That area, often referred to in the literature as "undivided Core Zone," has been interpreted by Poirier et al. (1990), Wardle et al. (2002) and Simard et al. (2013), based primarily on lithology and apparent continuity of aeromagnetic lineaments, as belonging to the Superior Craton. This interpretation is also supported by $\mathrm{U}-\mathrm{Pb}$ ages recently obtained on various intrusions that suggest an affinity with the adjacent Superior Craton (Rayner et al. 2017). In addition, the Superior Craton can be traced around the northernmost lobe of the Labrador Trough north of Kangirsuq (Fig. 2), suggesting that it forms the direct basement beneath at least that part of the Trough. Moreover, basement domes and nappes with Superior crust affinities occur west of Kuujjuaq (Machado et al. 1989), and in a tectonic window in the central part of the Trough (Wheeler Dome). In this paper, we focus our attention on the geological framework of that part of the Core Zone situated between the Lac
Tudor shear zone and the western edge of the Lac Lomier Complex, which we define herein as Core Zone sensu stricto (e.g. Wardle et al. 2002).

\section{GEOLOGY OF THE CORE ZONE}

For the most part, the Core Zone consists of variably transposed metaplutonic rocks, gneiss and migmatite that form North-South elongated crustal lenses, up to $500 \mathrm{~km}$ long and $100 \mathrm{~km}$ wide, separated by steeply dipping, ductile shear zones (Girard 1990b; Wardle and Van Kranendonk 1996). The metaplutonic rocks have yielded $\mathrm{U}-\mathrm{Pb}$ ages ranging from 2.6 to 3.0 Ga (Nunn et al. 1990; Ryan et al. 1991; Isnard et al. 1998, 1999; James and Dunning 2000), with one of the crustal blocks (Mistinibi-Raude) hosting predominantly supracrustal and plutonic rocks with the latter yielding a significantly younger and from a global perspective, relatively unusual age of $2.33 \mathrm{Ga}$ (Girard 1990a, c). Infolded remnants of a Paleoproterozoic cover sequence containing quartzite, marble, metapelite and rare ultramafic sills occur in the northeast part of the Core Zone and have been tentatively correlated with the Lake Harbour Group on Southern Baffin Island (Jackson and Taylor 1972; Scott and St-Onge 1998; Bourlon et al. 2002). 
A ca. 1.84-1.82 Ga continental magmatic arc suite, the De Pas Batholith, occurs close to the western edge of the Core Zone and appears to be mostly confined to the George River Block (van der Leeden et al. 1990; Dunphy and Skulski 1996; James and Dunning 2000). Wardle et al. (2002) pointed out that negative $\boldsymbol{\varepsilon}_{\mathrm{Nd}}$ values ranging from -7 to -3 obtained for the De Pas Batholith (Kerr et al. 1994; Dunphy and Skulski 1996) indicate significant contamination by Archean crust and suggested that parts of the batholith may be syn-collisional. The Core Zone is also host to a significant portion of the Mesoproterozoic Nain Plutonic Complex (Emslie and Hunt 1990). In the following sections we describe the various crustal blocks forming the Core Zone, which we define as the George River, Mistinibi-Raude and Falcoz River blocks. The George River Block correlates with the Crossroads and Orma domains identified farther south by James and Dunning (2000), and the Fal$\mathrm{CO}$ River Block amalgamates the Ford River, Henrietta, Anaktalik and Konrad Brook domains previously defined by Wardle et al. (2002) and references therein.

\section{George River Block}

The George River Block (Figs. 3 and 4), situated between the Lac Tudor and George River shear zones, is underlain by a distinct assemblage of metaplutonic and supracrustal rocks and is the main host to the ca. 1.84-1.82 Ga De Pas Batholith (Fig. $5 \mathrm{~A})$. Other than the batholith, its main lithology is the Archean (see below) Tunulik Belt (Lafrance et al. 2015), a supracrustal assemblage of mainly mafic to intermediate metavolcanic (Fig. 5B) and volcanogenic sedimentary rocks with rare felsic components. It also comprises a sub-volcanic plutonic root, composed of mixed, medium-grained, dioritic to granitic intrusions and quartz-feldspar porphyry (Fig. 5C), all intruded by megacrystic granite (Fig. 5D). The latter can be distinguished from the De Pas Batholith by its higher degree of recrystallization and migmatization. In contrast, the ca. 1.84-1.81 Ga De Pas Batholith is in general non-migmatitic, commonly preserving $\mathrm{K}$-feldspar megacrysts in a weakly to moderately foliated matrix. Metamorphic assemblages are indicative of midamphibolite facies throughout the George River Block, and structural fabrics are generally oriented north-south, becoming more intense and progressively steeper towards the bounding shear zones. Some of the De Pas plutons contain orthopyroxene, but it is an igneous phase.

\section{Falcoz River Block}

Between the George River/Moonbase and Abloviak shear zones (Fig. 3) lies an area dominated by Archean rocks. This area has historically been divided into several domains based on dominant rock composition, metamorphic grade and/or presence of Paleoproterozoic-age cover sequences. These were named the Ford River, Henrietta Lake, Anaktalik and Konrad Brook domains by Wardle et al. (1990) and Wardle and Van Kranendonk (1996). Considering their similar age ranges and apparent continuity on aeromagnetic maps (see sections below) we group them all into the larger Falcoz River Block. The most common lithologies are meta-plutonic rocks, orthogneiss and migmatite (Fig. 5E) metamorphosed at upper- amphibolite facies. In its northern extents, the Falcoz River Block hosts distinct charnockite and enderbite plutons that retain most of their original igneous feldspars (only partially recrystallized) and are interpreted as Proterozoic-age intrusions, possibly related to the Cumberland Batholith on Baffin Island (Bourlon et al. 2002). Throughout this block, strain is variable, displaying fabrics becoming progressively more transposed near bounding shear zones. In its eastern part, the Fal$\mathrm{COz}$ River Block contains a greater abundance of late-Archean (see below) granite intrusions, as well as a widespread cover sequence that comprises quartzite, metapelite and marble, with mafic and ultramafic sills near their base. This supracrustal sequence has been tentatively correlated with the Lake Harbour Group on Southern Baffin Island (Jackson and Taylor 1972; Scott and St-Onge 1998). The metamorphic facies in the eastern part of the domain is uppermost-amphibolite to incipient granulite facies. The fact that biotite-out reactions have occurred in metapelites of potential Lake Harbour Group affinity, as well as evidence for orthopyroxene-in reactions in mafic rocks, suggests that $>800^{\circ} \mathrm{C}$ temperatures have been reached during the Paleoproterozoic, at least locally. However, the possibility that granulite facies conditions may have also occurred during the Archean cannot be ruled out. Fabrics in the eastern half of the Falcoz River Block are relatively flat to shallow-dipping, forming dome and basin structures that are slightly elongated along a north-south axis. These structures progressively steepen towards the Falcoz and Abloviak shear zones, as well as towards their contact with the Lac Lomier Complex.

\section{Mistinibi-Raude Block}

The Mistinibi-Raude Block (Fig. 3) is situated between the Moonbase and George River shear zones and is compositionally and metamorphically distinct from the George River and Falcoz River blocks. It consists of a supracrustal belt (Ntshuku Belt) composed mainly of mafic metavolcanic rocks (Fig. 5F), with minor meta-andesite and rhyolite, associated with staurolite-garnet-cordierite-bearing metapelite, psammite and calcsilicate gneiss (Fig. 6A). The supracrustal rocks are intruded by a distinct suite of calc-alkaline sub-volcanic metaplutonic rocks that includes feldspar- and hornblende-phyric diorite, granodiorite and monzogranite (Pallatin suite), for which a preliminary $\mathrm{U}-\mathrm{Pb}$ zircon age of ca. $2.33 \mathrm{Ga}$ has been reported (Girard 1990a). The existence of a second, slightly more alkaline plutonic suite is suggested by the presence of large composite intrusions that consist of gabbro, monzogabbro, diorite, monzodiorite, quartz syenite, and augite syenite. Silica-saturated rocks of that suite commonly contains blue, rutilated quartz, as well as rare orthopyroxene- and blue quartz-bearing pegmatite, suggestive of emplacement at very high temperatures under locally anhydrous conditions. That more alkaline suite coincides with two strong magnetic anomalies on regional airborne aeromagnetic surveys (Fig. 4) that have been referred to as the Nekuashu and Pelland plutons (Lafrance et al. 2015, 2016). The Mistinibi-Raude Block also hosts a fluvial clastic sedimentary sequence, the Hutte Sauvage Group (van der Leeden 1994), which comprises meta-conglomerate and 


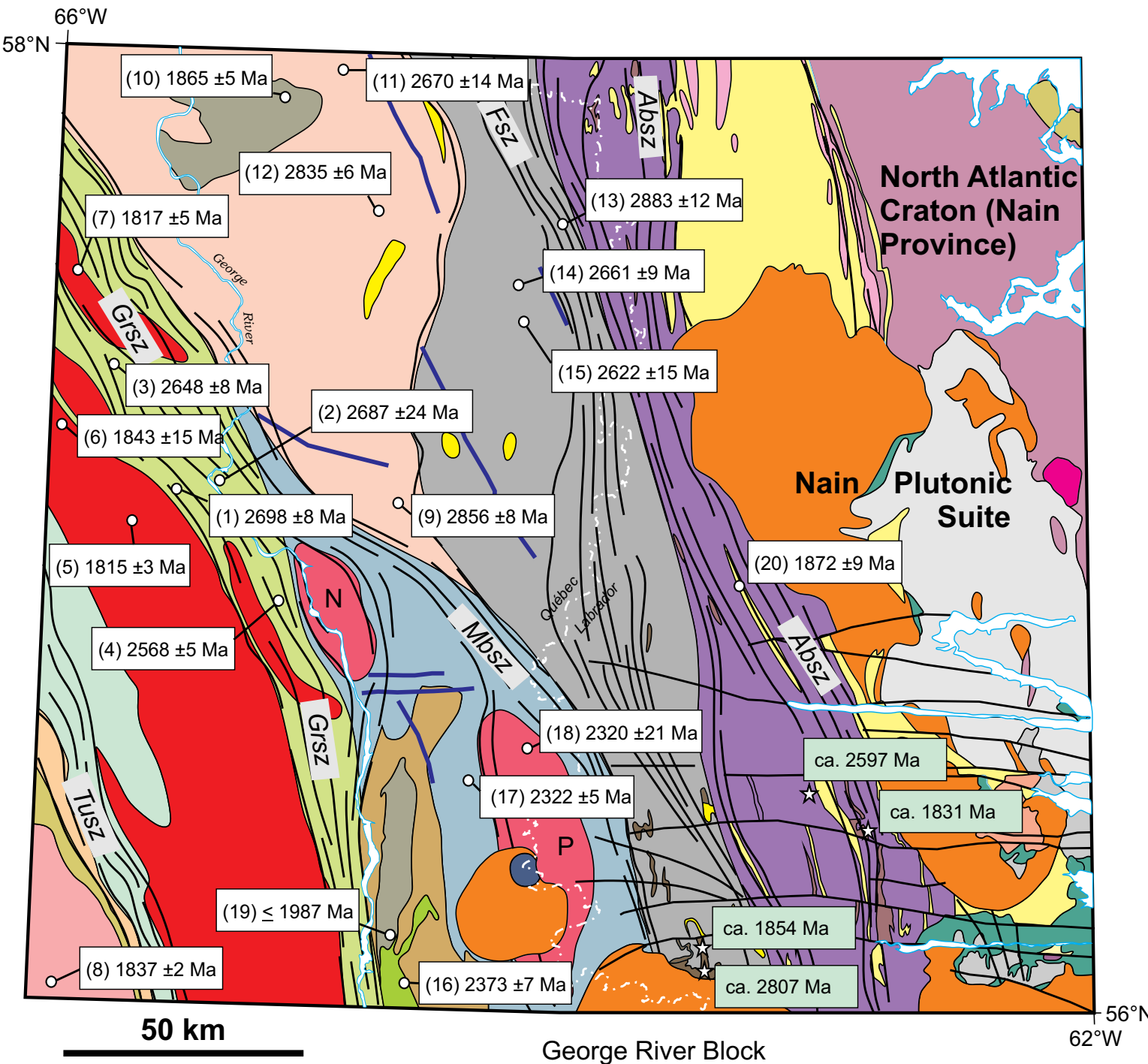

Nain Plutonic Complex

$\square$ Strange Lake alkali intrusion

Monzonite, granite, monzogranite

Gabbro, norite

Anorthosite

Mistinibi-Raude Block

$\square<1987$ Ma Hutte Sauvage Group

ca. 2.32 Ga alkalic intrusions

Mistinibi complex (migmatitic paragneiss)

Ntshuku volcanic belt (ca. 2.37 Ga)

ca. 2.3 - $2.6 \mathrm{Ga}$ orthogneiss

Kuujjuaq Domain (reactivated Superior basement)

$\square$ ca. 1.84 megacrystic granite (De Pas Batholith?)

Archean or Paleoproterozoic metasedimentary rocks

ca. 2.6 Ga metaplutonic rocks
1.84-1.82 Ga De Pas Batholith

Mainly metaplutonic rocks and orthogneiss

2.73-2.69 Ga Tunulik Supracrustal Belt

\section{Falcoz River Block}

$\square$ ca. $1.86 \mathrm{Ga}$ charnockite (Cumberland Batholith?)

ca. 1.90 Ga supracrustal cover (LHG)

Mafic granulite, amphibolite

Mainly granulite facies tonalite and granite

Mainly amphibolite facies tonalite and granite

North Atlantic Craton

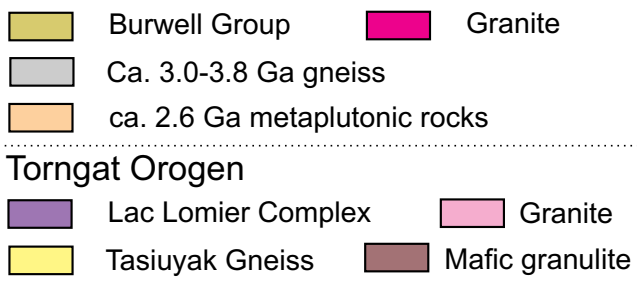

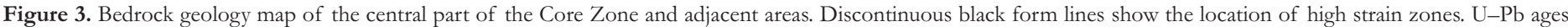

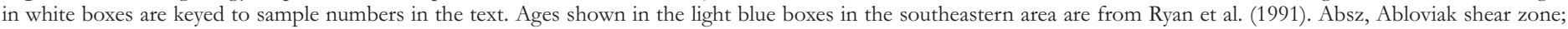
Fsz, Falcoz shear zone; Grsz, George River shear zone; Mbsz, Moonbase shear zone; Tusz, Lac Tudor shear zone. 


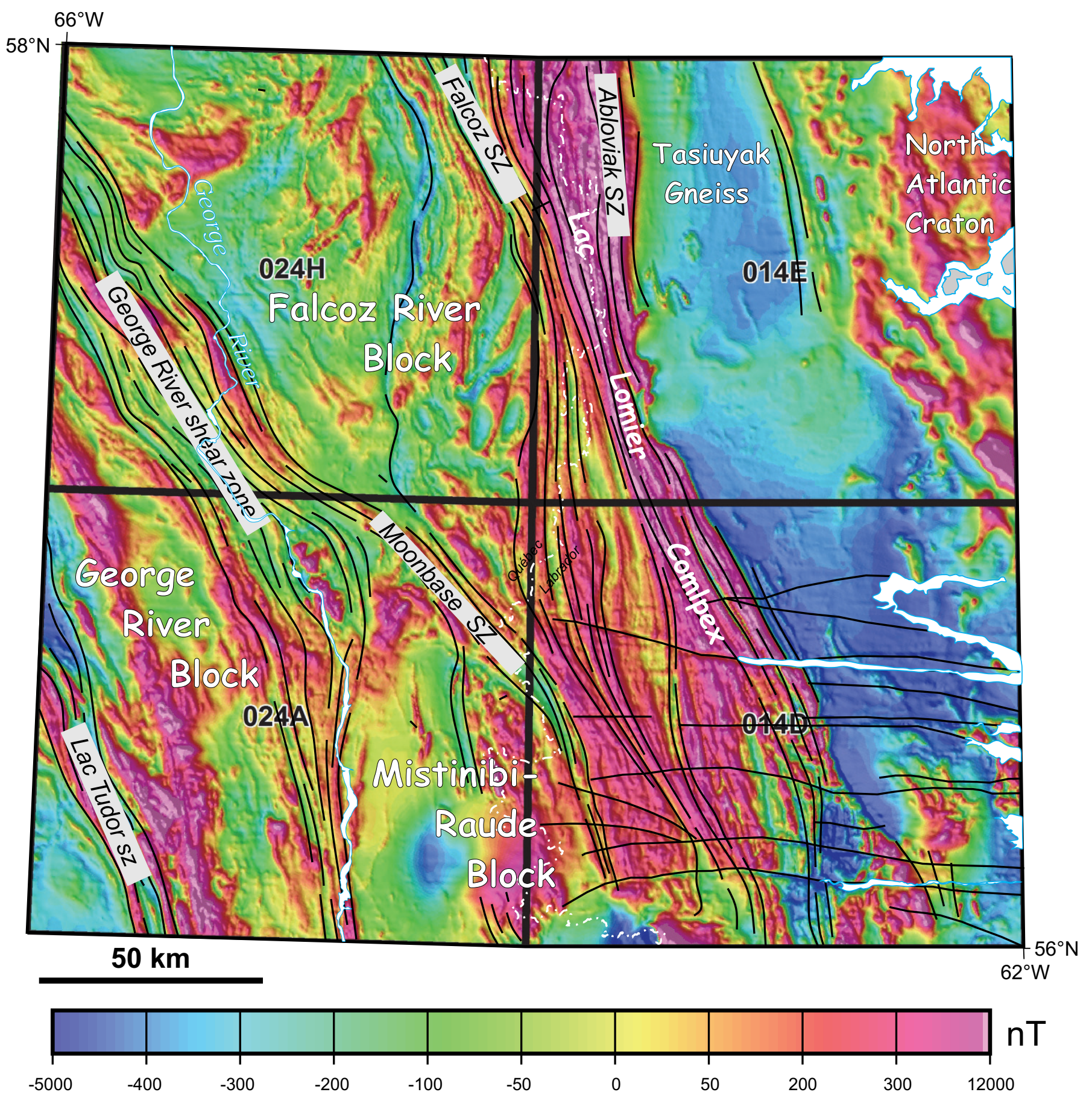

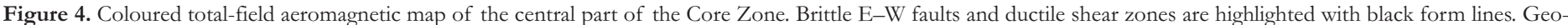
logical Survey of Canada database. 1:250,000-scale NTS map areas 014D, 014E, 024A and 024H are shown.

locally cross-bedded meta-arkose and quartzite (Fig. 6B). It was interpreted by Girard (1990a) as a post-1820 Ma sedimentary sequence based on the presence of clasts of $\mathrm{K}$-feldspar megacrystic granite inferred to have been derived from the De Pas Batholith. Metamorphism within the Mistinibi-Raude Block ranges from lower to upper amphibolite facies.

\section{Lac Lomier Complex}

The Lac Lomier Complex bounds the Core Zone on its east- ern side. It consists of metaplutonic rocks and orthogneiss of predominantly intermediate composition, but ranging overall from mafic to felsic in composition that is banded at the centimetre to metre scale. These rocks are metamorphosed at granulite facies, giving them a waxy green to light brown colour, and characteristically have orthopyroxene and hornblende as the main mafic phases (Fig. 6C).

The Lac Lomier Complex has been interpreted by Wardle et al. (1990) as a ca. 1.87 to $1.86 \mathrm{Ga}$ continental arc emplaced 

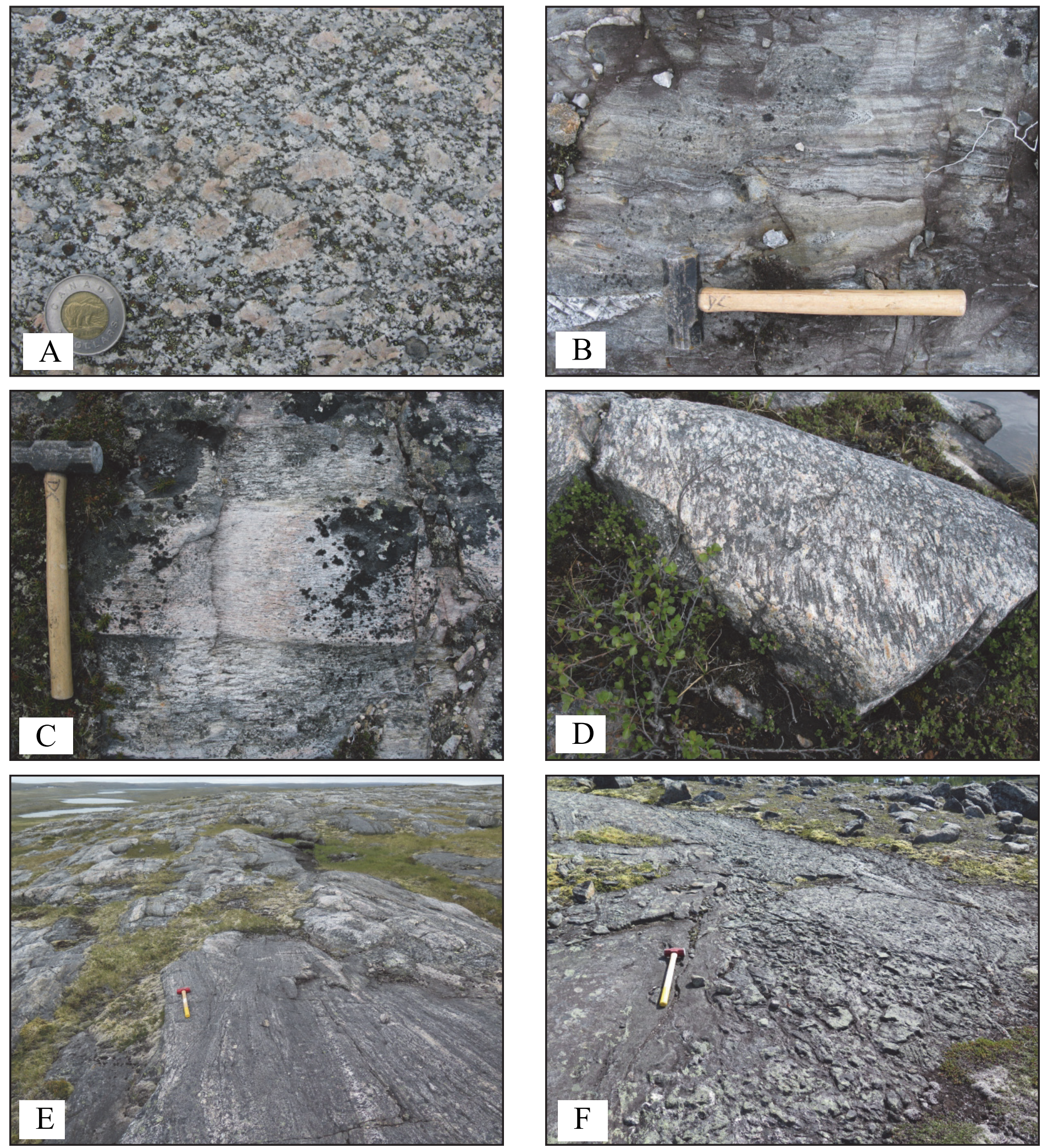

Figure 5. Field photographs from the Core Zone. A) K-feldspar megacrystic, hornblende-biotite granite from the De Pas Batholith. Coin for scale is 28 mm in diameter. B) Intermediate to felsic volcaniclastic rock outcrop from the Tunuliq Belt. Hammer for scale is $38 \mathrm{~cm}$ long. C) Sub-volcanic quartz-feldspar porphyry phase of the Tunuliq Belt (center of the photograph) intruding a coarser-grained granodioritic intrusion of likely similar age. Hammer for scale is $38 \mathrm{~cm}$ long. D) Metamorphosed and recrystallized $\mathrm{K}$ feldspar megacrystic granite that intrudes metavolcanic rocks of the Tunuliq Belt (geochronology Sample 4). Base of photograph is $1.5 \mathrm{~m}$ across. E) Field photograph of a typical outcrop in the Falcoz River Block, showing variably transposed orthogneiss. Hammer for scale is $38 \mathrm{~cm}$ long. F) Outcrop photograph of flow breccia (right side of photo) in Ntshuku Belt basaltic rock. Hammer for scale is $38 \mathrm{~cm}$ long.

http://www.geosciencecanada.ca 

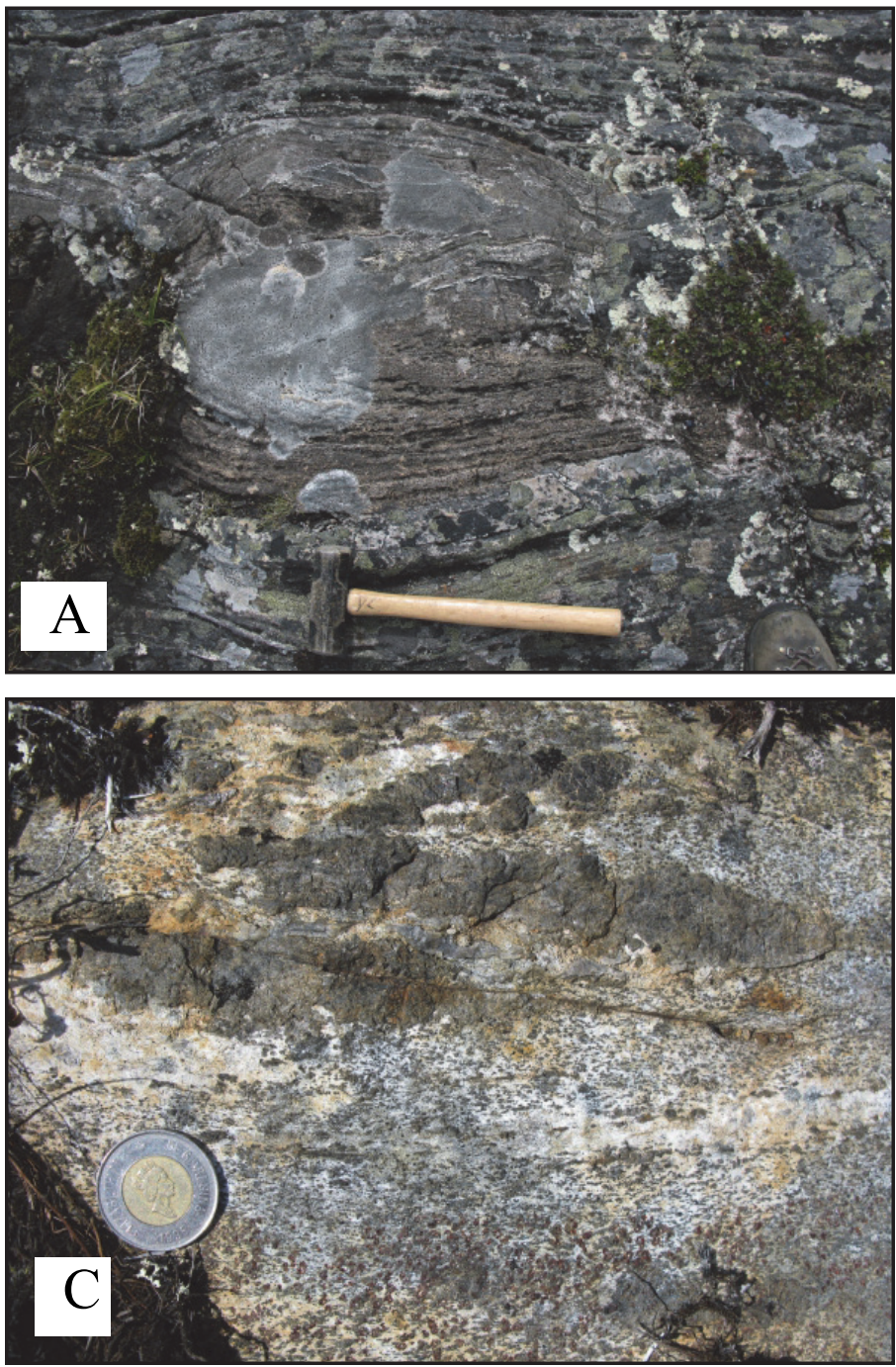

roxene crystals (brown colour, top of photograph) in mafic to intermediate granulite of the Lac Lomier Complex. Coin for scale is 28 mm in diameter.

on the western margin of the North Atlantic Craton. The presence of map-scale screens of metapelitic rocks, likely derived from the Tasiuyak Gneiss, lends support to that interpretation. Overall, the Lac Lomier Complex is highly strained, with the very strong transposition of lithological layers forming a steeply-dipping gneiss with a pervasive, sub-horizontal mineral and stretching lineation. Kinematic indicators show a consistent dextral strike-slip sense of shear. Its contact with the Falcoz River Block is relatively sharp and appears to be structural.

\section{ANALYTICAL PROCEDURES}

Two different analytical techniques, performed in separate laboratories, were used to generate $\mathrm{U}-\mathrm{Pb}$ ages. Eleven samples were analyzed using the sensitive high-resolution ion microprobe (SHRIMP) at the Geological Survey of Canada (GSC), and nine samples were analyzed by laser ablation, inductively coupled plasma mass spectrometry (LA-ICPMS) at the Department of Earth Sciences, University of New Brunswick. Four samples from the George River Block (samples 1, 3, 4

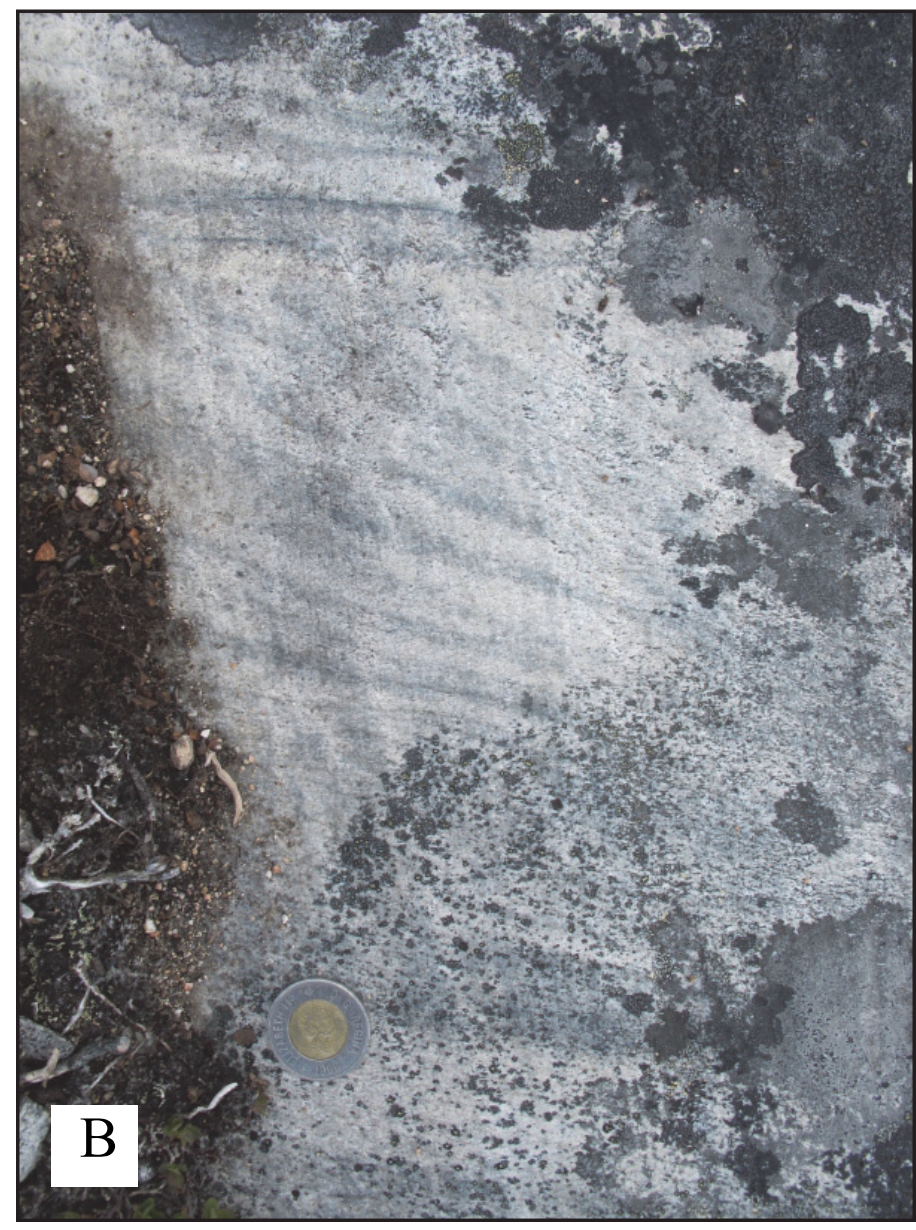

Figure 6. Outcrop photographs from the Core Zone. A) Folded calc-silicate gneiss from the Ntshuku supracrustal belt, suggesting shallow-marine depositional environment. Hammer for scale is $38 \mathrm{~cm}$ long. B) Cross-bedded meta-arkose from the Hutte Sauvage Group (Sample 19). This outcrop is a few hundreds of metres above a conglomerate horizon. Coin for scale is $28 \mathrm{~mm}$ in diameter. C) Very large orthopy-

and 5), one from the Falcoz River Block (Sample 9), four from the Mistinibi-Raude Block (samples 16 to 19), and one from the Lac Lomier Complex (Sample 20) were analyzed using SHRIMP. The zircon separates were prepared using standard crushing, grinding, Wilfley ${ }^{\mathrm{TM}}$ table, and heavy liquid techniques, followed by magnetic susceptibility sorting using a Frant $\mathrm{z}^{\mathrm{TM}}$ isodynamic separator. SHRIMP analytical procedures followed those described by Stern (1997), utilizing standards and $\mathrm{U}-\mathrm{Pb}$ calibration methods following Stern and Amelin (2003). Briefly, zircons were cast in $2.5 \mathrm{~cm}$ diameter epoxy mounts along with fragments of the GSC laboratory standard zircon $\left(\mathrm{z} 6266\right.$, with a ${ }^{206} \mathrm{~Pb} /{ }^{238} \mathrm{U}$ age of $\left.559 \mathrm{Ma}\right)$. The mid-sections of the zircon grains were exposed and polished using 9 , 6 , and $1 \mu \mathrm{m}$ diamond compound, and the internal features of the grains (such as zoning, structures, alteration, etc.) were imaged in back-scattered electron mode (BSE) or in cathodoluminescence (CL) utilizing a Zeiss Evo 50 scanning electron microscope. Mount surfaces were evaporatively coated with 10 $\mathrm{nm}$ of high-purity Au. Analyses were conducted using a ${ }^{16} \mathrm{O}$ primary beam, projected onto the zircon at $10 \mathrm{kV}$. The count 
rates at eleven masses, including background, were sequentially measured with a single electron multiplier. Off-line data processing was accomplished using SQUID2 (version SQUID 2.50.11.10.15, rev. 15 Oct. 2011) software written by Ludwig (2003). The $1 \sigma$ external errors of ${ }^{206} \mathrm{~Pb} /{ }^{238} \mathrm{U}$ ratios reported in supplementary data Table S-1 incorporate the error in calibrating the standard. The common $\mathrm{Pb}$ correction utilized $\mathrm{Pb}$ composition of the surface blank (Stern 1997). Yb and Hf concentration data were calculated using sensitivity factors derived from standard z6266 with values of 69 and 8200 ppm, respectively. Analyses of a secondary internal zircon standard (z1242, with an accepted age of $2679.7 \pm 0.2 \mathrm{Ma}$ (B. Davis, personnel communication)) were interspersed between the sample analyses to monitor $\mathrm{Pb}$ isotopic fractionation. Isoplot v. 4.15 (Ludwig 2003) was used to generate Concordia plots and the probability density diagram for detrital Sample 19, and to calculate weighted means. The error ellipses on the Concordia diagrams and the weighted mean errors are reported at $2 \sigma$.

$\mathrm{U}-\mathrm{Pb}$ analyses for samples 2, 6, and 7 from the George River Block, and samples 10 to 15 from the Falcoz River Block were processed at the Department of Earth Sciences geochronology laboratory, University of New Brunswick. Zircon U-Pb dating was carried out using a Resonetics RESOlution M-50 series $193 \mathrm{~nm}$ excimer laser ablation system equipped with a Laurin Technic Pty S-155 ablation cell. Ablation was conducted in a mixed $\mathrm{He}(325 \mathrm{~mL} / \mathrm{min})$ and $\operatorname{Ar}(930$ $\mathrm{mL} / \mathrm{min})$ carrier gas and mixed with $\mathrm{N}_{2}(2 \mathrm{~mL} / \mathrm{min})$ downstream of the cell. Contamination at mass 204 from $\mathrm{Hg}$ in the carrier gases was $<150 \mathrm{cps}$. Data listed in supplementary Table S-2 were collected using either 17 or $24 \mu \mathrm{m}$ diameter laser crater depending on the size of the grains, a repetition rate of $4.5 \mathrm{~Hz}$, and laser fluence of $\sim 4 \mathrm{~J} / \mathrm{cm}^{2}$. The data were standardized against FC1 zircon $(1099 \pm 2 \mathrm{Ma})$ which was distributed evenly throughout the sequence and analyzed at least 16 times per run. Each ablation was 35 seconds in duration and was preceded by $40 \mathrm{sec}$ of background collection. Ablated aerosol was transferred to the ICP-MS using nylon tubing with an in-line 'squid' smoothing device connected immediately before the junction with the ICP-MS torch. Isotope intensities were measured using an Agilent 7700x quadrupole-ICP-MS operated in 'auto' detector mode: sensitivity and P/A factors were tuned by rastering across NIST610 glass before the start of each run. A second external rotary pump was used to enhance sensitivity. The ICP-MS method measured ${ }^{90} \mathrm{Zr},{ }^{202} \mathrm{Hg}$, ${ }^{204} \mathrm{~Pb},{ }^{206} \mathrm{~Pb},{ }^{207} \mathrm{~Pb},{ }^{208} \mathrm{~Pb},{ }^{232} \mathrm{Th}$ and ${ }^{238} \mathrm{U}$ with a total quadrupole sweep time of 0.23 seconds. The background corrected ${ }^{202} \mathrm{Hg}$ ion beam measured during ablation was used to peak strip any small excess ${ }^{204} \mathrm{Hg}$ from the ${ }^{204} \mathrm{~Pb}$ signal using the ${ }^{202} \mathrm{Hg} /{ }^{204} \mathrm{Hg}$ measured on the gas background. The magnitude of this correction was typically insignificant. The data were reduced offline using VizualAge (Petrus and Kamber 2012) and Iolite v2.5 (Paton et al. 2011) running as plugins in Wavemetrics Igor Pro 6.23. Concentration data were calculated relative to NIST610 (distributed throughout the sequence) and using the Iolite trace-elements "internal standardization" data reduction scheme. An estimated value of $44 \mathrm{wt}^{\%} \% \mathrm{Zr}$ in zircon was used as the internal standard composition. Common $\mathrm{Pb}$ was cor- rected using the background-corrected and $\mathrm{Hg}$-interference corrected ${ }^{204} \mathrm{~Pb}$ intensity, a common- $\mathrm{Pb}$ composition based on the $\mathrm{Pb}-\mathrm{Pb}$ evolution curve of Stacey and Kramers (1975) and an estimate of the age of the zircon based on the uncorrected ${ }^{206} \mathrm{~Pb} /{ }^{238} \mathrm{U}$ age. This correction method is suitable for grains with modest common- $\mathrm{Pb}$ content and minor Pb-loss. The $\% \mathrm{~Pb}^{*}$ estimate reported in supplementary data Table S-2 was taken from the Andersen (2002) routine implemented in VizualAge. A summary of U-Pb ages is presented in Table 1.

\section{RESULTS}

Samples for dating were principally collected from the George River, Mistinibi-Raude and Falcoz River blocks of the Core Zone sensu stricto, with one each coming from the adjacent Kuujjuaq Block and Lac Lomier Complex to the west and east, respectively.

\section{George River Block}

Seven rock units were sampled from the George River Block, providing age constraints on the Tunulik volcanic belt, gneiss and migmatite associated with this belt, as well as late plutonism interpreted to be associated with the De Pas Batholith. Results are as follows:

\section{Sample 1: Tunulik Meta-Rhyolite (14CXA-D90A1; SHRIMP)}

The Tunulik meta-rhyolite is medium-grained, well-foliated and metamorphosed at mid- to upper amphibolite facies. It yielded numerous, clear, colourless, short prismatic zircon grains with internal oscillatory growth zoning and thick to thin unzoned rims likely of metamorphic origin (Fig. 7A). Thirty of the $32 \mathrm{U}-\mathrm{Pb}$ SHRIMP analyses fall into two main groupings with oscillatory zoned material yielding a weighted mean ${ }^{207} \mathrm{~Pb} /{ }^{206} \mathrm{~Pb}$ age of $2698 \pm 8 \mathrm{Ma}(\mathrm{n}=20 / 23$; MSWD $=1.20$, probability of fit $(\mathrm{POF})=0.25)$, interpreted as the timing of volcanism, and unzoned rims giving a weighted mean age of $2543 \pm 20 \mathrm{Ma}(\mathrm{MSWD}=0.28, \mathrm{POF}=0.92)$, interpreted as the time of metamorphic zircon crystallization or recrystallization. The two oldest analyses from this sample, with low U contents (17-19 ppm) and strongly discordant ages of 2855 and 2807 $\mathrm{Ma}$, are interpreted to represent xenocrystic material.

\section{Sample 2: Migmatitic Granodiorite (14CXA-D92A1; LA- ICPMS)}

Sample 2 is from a complex outcrop that includes gneissic and migmatitic orthogneiss of predominantly felsic to intermediate composition. Field relationships suggest that it may comprise the oldest component of the George River Block and a granodiorite paleosome was sampled for dating. This sample contained small (10-150 $\mu \mathrm{m}$ long and approximately $50 \mu \mathrm{m}$ wide) colourless to pale brown to dark brown zircons. Numerous grains are murky and turbid and moderately cracked. High-U cores surrounded by reddish-brown damage zones are locally visible in the transmitted light image. The cathode luminescence (CL) response is strongly quenched (high U content) and a combination of faint planar and locally oscillatory zoning is visible. The $\mathrm{U}-\mathrm{Pb}$ data for this sample displays a combination 


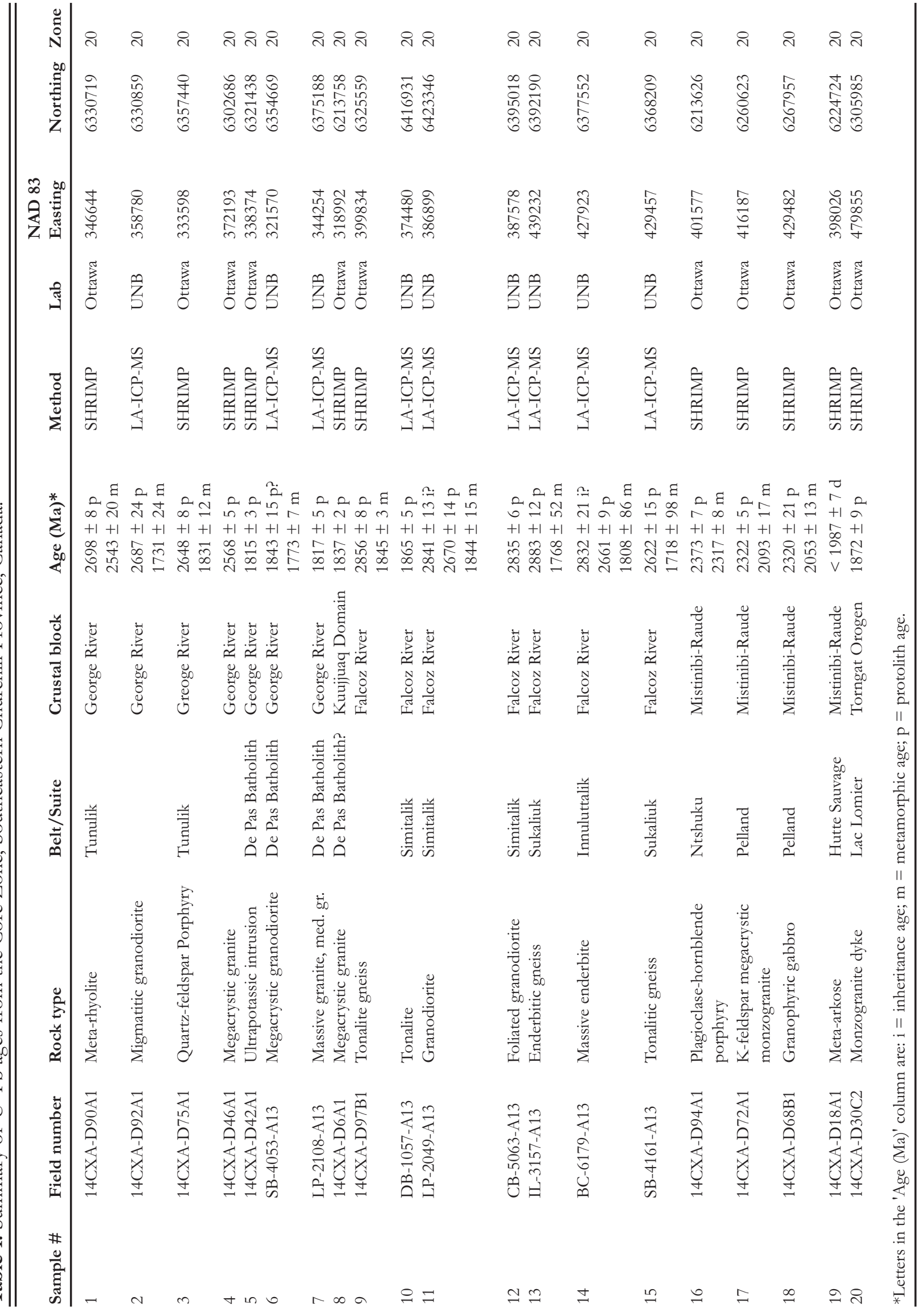



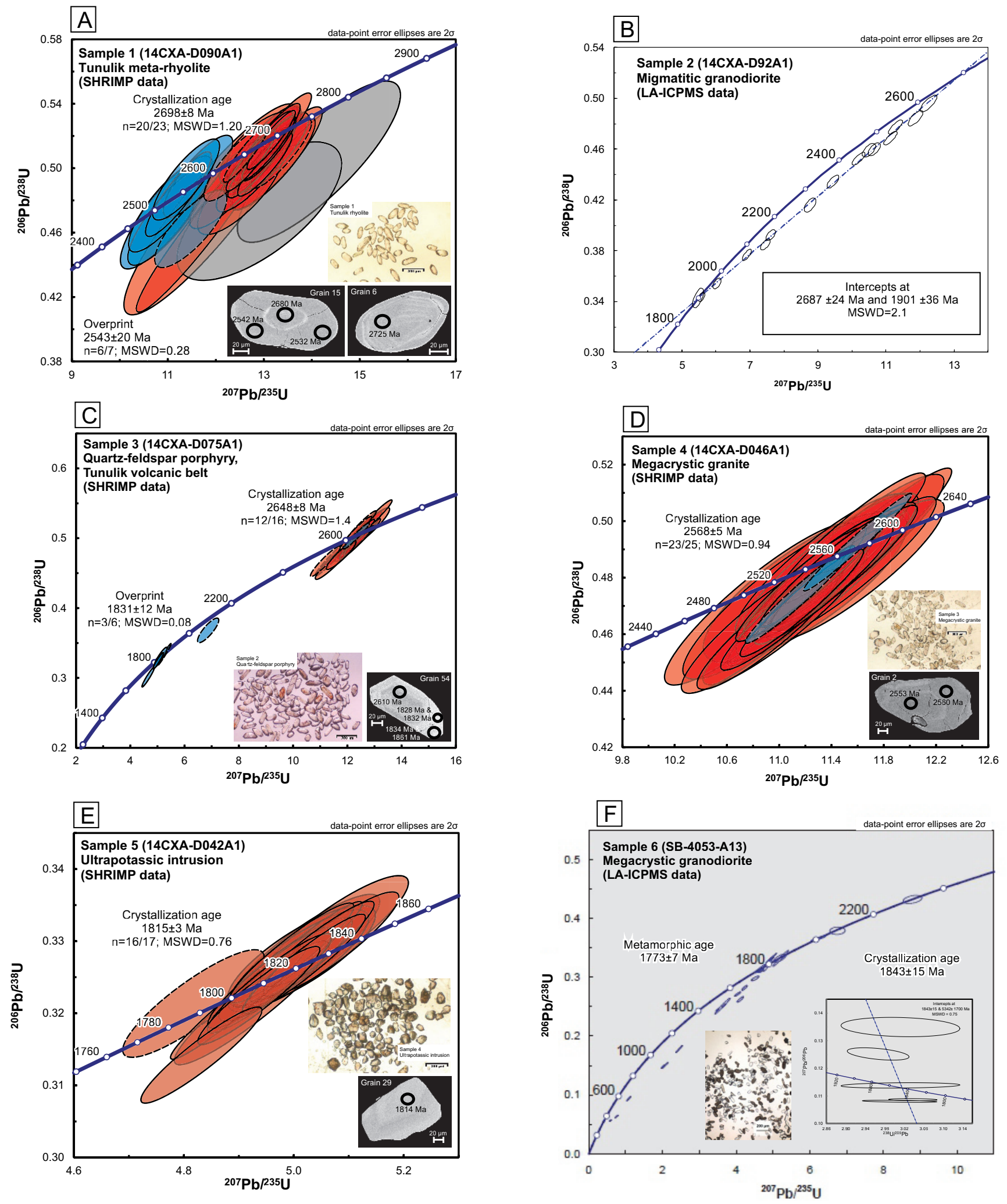

Figure 7. Concordia diagrams ( $2 \sigma$ errors), transmitted light images of zircon, and/or BSE SEM images of representative zircon crystals for rock units from the George River Block. A) SHRIMP data for Tunulik meta-rhyolite Sample 1; B) LA-ICP-MS data for Sample 2, a granodiorite paleosome; C) SHRIMP data for quartz-feldspar porphyry Sample 3; D) SHRIMP data for megacrystic granite Sample 4; E) SHRIMP data for ultrapotassic intrusion Sample 5; F) LA-ICP-MS data for Sample 6, a megacrystic granodiorite from the De Pas Batholith. In SHRIMP Concordia diagrams, red ellipses correspond to analyses from magmatic zircon, blue ellipses to recrystallized or newly grown zircon, and grey ellipses to xenocrystic zircon or inherited components within zircon. Dashed ellipses not included in weighted mean age calculations. In BSE SEM images, circles indicate approximate locations of analyses with corresponding ${ }^{207} \mathrm{~Pb} /{ }^{206} \mathrm{~Pb}$ ages. 
of recent and ancient Pb-loss as well as the effects of small and variable common- $\mathrm{Pb}$ incorporation (Fig 7B). To avoid effects of common- $\mathrm{Pb}$ incorporation, the data were filtered to consider only analyses that encountered $>98 \% \mathrm{~Pb}^{*}$ (as estimated using the Andersen (2002) routine in VizualAge) as well as ${ }^{206} \mathrm{Pbcps} /{ }^{204} \mathrm{Pbcps}>1000$. This yielded a subset of data that defines a discordia with an upper intercept of $\sim 2700 \mathrm{Ma}$ and a lower intercept of $\sim 1800 \mathrm{Ma}$. The Isoplot 'residuals' technique was used to refine this discordia to a statistically meaningful $(\mathrm{MSWD}=2.1)$ regression line with an upper intercept of $2687 \pm 24 \mathrm{Ma}$ and a lower intercept $1901 \pm 36 \mathrm{Ma}$.

\section{Sample 3: Sub-volcanic Quartz-Feldspar Porphyry (14CXA-D75A1; SHRIMP)}

Supracrustal rocks of the Tunulik Belt are intruded by sheets and dykes of mostly felsic quartz-feldspar porphyry that were interpreted in the field as sub-volcanic intrusions (Fig. 5C). They are mostly recrystallized except for the up to 5-10 mmsized phenocrysts which locally preserve unrecrystallized cores. Sample 3 was taken near the George River shear zone, where different rocks of the Tunulik Belt are transposed into sub-parallelism and have been metamorphosed at mid- to upper-amphibolite facies during deformation. Zircon crystals form euhedral, short to elongate prisms with well-developed internal oscillatory zoning. Several grains have bright, thin to thick rims (see Fig. 7C). The twelve oldest SHRIMP U-Pb analyses of oscillatory zoned zircon yield a weighted mean age of $2648 \pm 8 \mathrm{Ma}(\mathrm{n}=12 / 16$; MSWD $=1.4, \mathrm{POF}=0.16)$ interpreted as the crystallization age of the porphyry. Analyses of the bright rims yield a range of concordant to discordant ages between 2613 and $1828 \mathrm{Ma}$. The three youngest analyses from this population give a weighted mean age of $1831 \pm 12 \mathrm{Ma}$ $(\mathrm{MSWD}=0.083, \mathrm{POF}=0.92)$ interpreted as the time of deformation and amphibolite facies metamorphism along the George River shear zone. The other three rim analyses with ages $>1861 \mathrm{Ma}$ were excluded from the weighted mean as they may reflect incomplete resetting of the $\mathrm{U}-\mathrm{Pb}$ system during metamorphic recrystallization.

\section{Sample 4: Recrystallized Megacrystic Granite (14CXA- D46A1; SHRIMP)}

Sample 4 is from a megacrystic granite that intrudes the Tunulik Belt and associated metaplutonic and gneissic rocks. It compositionally resembles the K-feldspar megacrystic rocks of the De Pas Batholith but, in contrast to the latter, contains totally recrystallized K-feldspar megacrysts (Fig. 5D) and appears to have been affected by a more complex metamorphic and deformation history. Zircons from this rock occur as euhedral to subhedral, short to elongate prisms that exhibit mostly diffuse oscillatory zoning. A subset of grains has bright rims. All U-Pb SHRIMP analyses, from both oscillatory zoned interior regions and bright rims, define a relatively tight grouping (Fig.7D) indicating that the observed internal structure reflects compositional zonation. Excluding the two high-U, precise rim analyses, the remaining 23 analyses yield a weighted mean age of $2568 \pm 5 \mathrm{Ma}(\mathrm{MSWD}=0.94 ; \mathrm{POF}=0.54)$, interpreted as the crystallization age of the megacrystic granite.
This age is slightly older than, but within error of, the age of metamorphic rims from the Tunulik meta-rhyolite (Sample 1), indicating a potential link between emplacement of the Archean megacrystic granite and regional metamorphism in the George River Block.

\section{Sample 5: Ultrapotassic Intrusion, De Pas Batholith (14CXA-D042A1; SHRIMP)}

This very weakly deformed, biotite and K-feldspar rich, locally riebeckite- and epidote-bearing plutonic rock is spatially associated with the De Pas Batholith but its temporal relationship with it remains obscure. Zircon from this rock occurs as glassy, colourless to light brown, subrounded, anhedral to subhedral fragments. A number of grains exhibit faint broad zoning. U$\mathrm{Pb}$ SHRIMP analyses on 16 of 17 zircon fragments yielded a weighted mean age of $1815 \pm 3 \mathrm{Ma}(\mathrm{MSWD}=0.76$, POF $=$ 0.72), interpreted as the age of crystallization (Fig. 7E). This age is distinctly younger than the mostly 1840-1830 Ma age range reported for the De Pas Batholith (e.g. Wardle et al. 2002; this paper), and could indicate the presence of a later, more metasomatized phase of the intrusion.

\section{Sample 6: Megacrystic Granodiorite, De Pas Batholith (SB-4053-A13; LA-ICPMS)}

This sample is from a moderately foliated K-feldspar megacrystic granodiorite from the northern part of the De Pas Batholith (Fig. 3). It contains murky-brown to pale brown zircons that form prisms with slightly rounded edges. Analyses show abundant Pb-loss in the majority of grains (Fig. 7F), but the five spots shown in the inset on the figure define an inverse isochron lower-intercept age of $\sim 1843 \pm 15 \mathrm{Ma}$, interpreted as age of emplacement. A younger array of normally-discordant spots defines an upper intercept age of $1773 \pm 7 \mathrm{Ma}$, interpreted as the age of metamorphism. This crystallization age, together with the previous sample (Sample 5) corroborates with the known age range of the De Pas Batholith, which is generally accepted as ca. 1.84-1.82 Ga (Wardle et al. 2002).

\section{Sample 7: Massive Granite, De Pas Batholith (LP-2108- A13; LA-ICPMS)}

Sample 7 is a homogeneous, medium-grained, weakly foliated granite that represents a late phase of the De Pas Batholith. The zircons are long prismatic grains with rounded edges and are murky to light brown. LA-ICP-MS analyses have yielded a set of near-concordant points lying along an array between 1900 and $1750 \mathrm{Ma}$ (Fig. 8A), with a cluster of five overlapping concordant points at $1817 \pm 5 \mathrm{Ma}$, interpreted as the age of the intrusion. Another subset of points shows an inheritance at about 2.6 Ga. Data points trailing to older ages may represent inadvertent incorporation of older inherited components, whereas data points trailing down towards younger ages could represent either ancient $\mathrm{Pb}$-loss or placement of spots astride narrow younger overgrowths.

Sample 8: K-feldspar Megacrystic Granite (14CXA-D6A1; SHRIMP)

Sample 8 is from a K-feldspar-megacrystic granite that has 

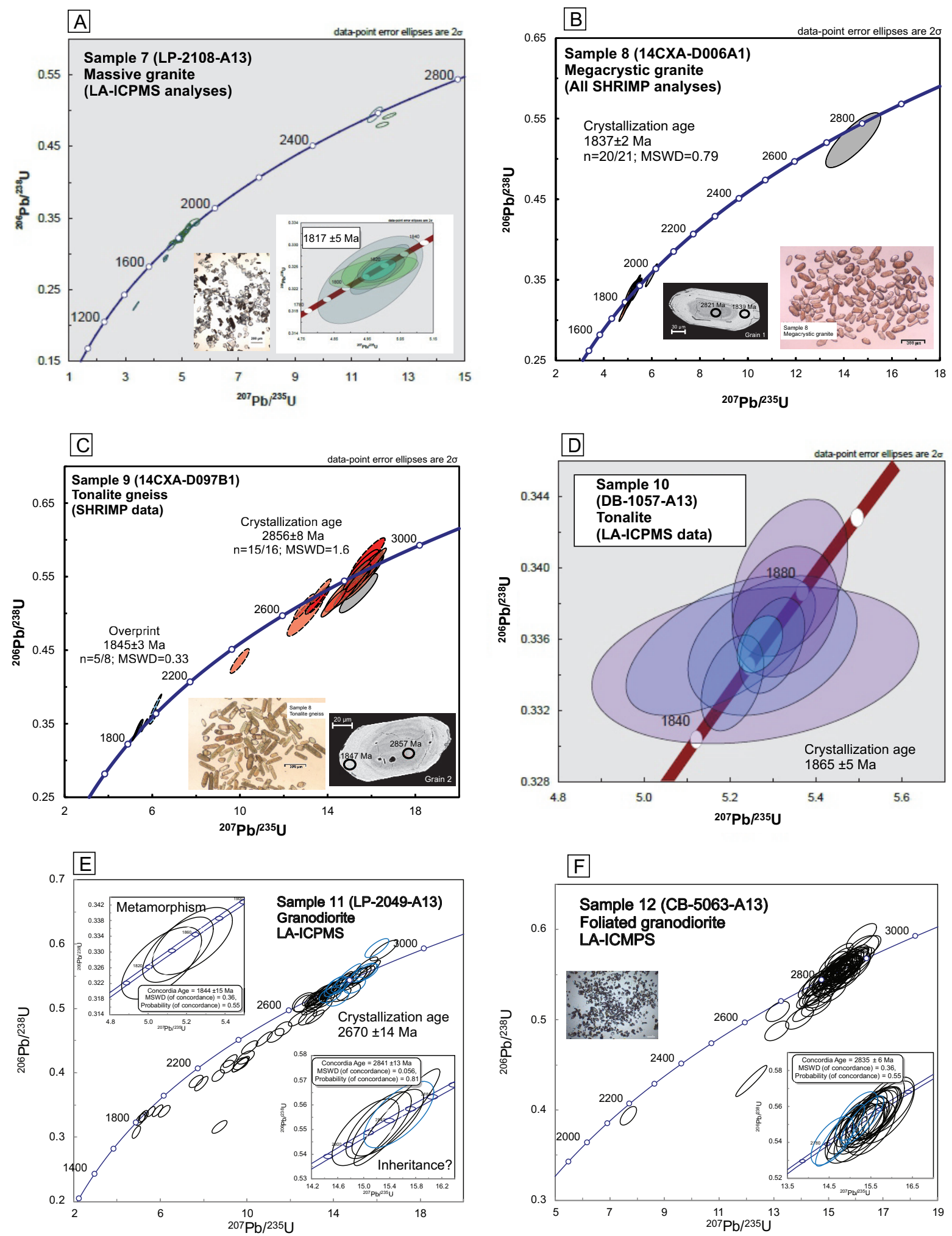

Figure 8. Concordia diagrams ( $2 \sigma$ errors), transmitted light images of zircon, and/or BSE SEM images of representative zircon crystals for rock units from the George River and Falcoz River blocks, as well as Kuujjuaq Domain. A) LA-ICP-MS data for Sample 7, a late, massive granite phase of the De Pas Batholith, George River Block; B) SHRIMP data for K-feldspar megacrystic granite Sample 8, Kuujiuaq Domain; C) SHRIMP data for Sample 9, a tonalite gneiss from the Falcoz River Block; D) LA-ICP-MS data from Sample 10, a tonalite from the Simitalik Suite in the Falcoz River Block; E) LA-ICP-MS data from Sample 11, a foliated granodiorite from the Falcoz River Block; F) LA-ICPMS data from Sample 12, a foliated granodiorite from the Falcoz River Block. In SHRIMP Concordia diagrams, red ellipses correspond to analyses from magmatic zircon, blue ellipses to recrystallized or newly grown zircon, and grey ellipses to xenocrystic zircon or inherited components within zircon. Dashed ellipses not included in weighted mean age calculations. In BSE SEM images, circles indicate approximate location of analyses with corresponding ${ }^{207} \mathrm{~Pb} /{ }^{206} \mathrm{~Pb}$ ages. 
intruded strongly deformed Archean gneiss of the Kuujjuak Domain, located a few kilometres west of the Lac Tudor shear zone, and therefore lies outside of the George River Block. From a compositional and textural perspective, it is indistinguishable from rocks of the De Pas Batholith. This unit was sampled to test if it could potentially belong to the De Pas Batholith, or from a different, possibly Archean suite emplaced in the Kuujjuaq Domain, hence on the reactivated and tectonically uplifted margin of the Superior Craton. It contains abundant, colourless to brown prismatic zircon. The majority of the grains are fractured and contain inclusions. Twenty SHRIMP analyses from fine-scale, oscillatory-zoned zircon (Fig. 8B) with a wide range of uranium concentrations (184 $1961 \mathrm{ppm}$ ) yield a weighted mean ${ }^{207} \mathrm{~Pb} /{ }^{206} \mathrm{~Pb}$ age of $1837 \pm 2$ Ma (MSWD $=0.79$, POF $=0.71$ ), interpreted as the crystallization age of the granite. The youngest analysis (11305053.2) was excluded from the weighted mean calculation as it overlapped the edge of the grain. The five oldest analyses from faintly zoned, relatively low-U cores with ages between 2821 and $1847 \mathrm{Ma}$ are interpreted to be inherited from surrounding plutonic rocks. This new age demonstrates that satellite intrusions related to the De Pas Batholith do in fact occur on either side of the Lac Tudor Shear Zone, and implications are discussed further down in the text.

\section{Falcoz River Block}

\section{Sample 9: Tonalite Gneiss (14CXA-D97B1; SHRIMP)}

Sample 9 is from a tonalite gneiss that forms a large part of the Falcoz River Block. It is medium to light grey in colour and typically migmatitic. Zircon grains, extracted from a nonmigmatitic portion of the unit, occur mostly as brown to colourless, oscillatory zoned prisms to faintly zoned or unzoned equant grains. Many grains are highly turbid and show extensive alteration in SEM BSE images. U-Pb SHRIMP analysis of oscillatory zoned interior regions show a distinct grouping of analyses at $2856 \pm 8 \mathrm{Ma}(\mathrm{n}=15 / 16$; MSWD $=$ 1.6, $\mathrm{POF}=0.084$ ), interpreted as the crystallization age of the tonalitic protolith (Fig. 8C). The single oldest analysis at 2920 $\mathrm{Ma}$ is interpreted to be inherited. It is unclear whether the cluster at ca. $2.73 \mathrm{Ga}$, which included faintly zoned to unzoned equant crystals, reflects new growth of zircon or $\mathrm{Pb}$ loss from ca. $2.856 \mathrm{Ga}$ zircon. Analyses from bright, recrystallized domains (rims or interiors of grains) with distinctly high uranium concentrations (1363-2468 ppm) and low Th/U ratios $(<0.09)$ yield a weighted mean age of $1845 \pm 3 \mathrm{Ma}$ (MSWD $=0.33$, POF $=0.86)$, interpreted as the age of peak metamorphism that led to regional anatexis. Three high- $U$ analyses with older ${ }^{207} \mathrm{~Pb} /{ }^{206} \mathrm{~Pb}$ ages $(1989-1918 \mathrm{Ma}$ ) were excluded from this mean age calculation since they show incomplete resetting as a result of this recrystallization event.

\section{Sample 10: Tonalite (DB-1057-A13; LA-ICPMS)}

Sample 10 is from a massive to weakly foliated, biotite-hornblende tonalite from the Simitalik Suite in the Falcoz River Block. Plagioclase crystals are mostly light grey to purplish in colour and not recrystallized. It contains abundant pale-brown elongate zircon crystals with rounded terminations and obvious core-overgrowth relationships, as well as abundant apatite. The U-Pb data displays a combination of Pb-loss as well as the effects of high common- $\mathrm{Pb}$ content. A variety of inherited ages were encountered ranging from $2720 \mathrm{Ma}$ to $2100 \mathrm{Ma}$. There is a more coherent cluster of near-concordant data with ${ }^{207} \mathrm{~Pb} /{ }^{206} \mathrm{~Pb}$ ages of ca. $1860 \mathrm{Ma}$ (Fig. 8D). Within this cluster a set of 6 concordant analyses define a Concordia age of 1865 $\pm 5 \mathrm{Ma}$, which is taken as the best estimate of the zircon crystallization age. This age is similar to those reported from the Cumberland Batholith on Southern Baffin Island (Scott and St-Onge 1998), suggesting a possible link. Alternatively, it could indicate an earlier age of formation for the De Pas Batholith, but its petrology and texture is sufficiently different from other De Pas Batholith units to cast doubts on an unambiguous association.

\section{Sample 11: Granodiorite (LP-2049-A13; LA-ICPMS)}

Sample 11 is from a massive, homogeneous granodiorite of the Simitalik Suite that has intruded tonalitic to granitic orthogneisses and migmatites in the Falcoz River Block. It contains abundant colourless to brown zircon prisms ranging from $20-250 \mu \mathrm{m}$ in length and $10-100 \mu \mathrm{m}$ in width. Single crystals and broken fragments display terminations ranging from sharp pyramidal to subrounded shapes. Concentric oscillatory zoning is locally visible in larger brown grains. Optical CL imaging revealed pale yellow to grey oscillatory-zoned cores surrounded by blue-grey luminescent domains also containing combinations of faint oscillatory and rare convoluted or sector zoning. Zircon data for Archean components from a continuous array between $2841 \pm 13 \mathrm{Ma}$ and $2670 \pm 14 \mathrm{Ma}$ that is best interpreted as a mixing line between older inherited components and magmatic zircon overgrowths. Thus, $2670 \pm$ $14 \mathrm{Ma}$ (Fig. 8E) is interpreted as the age of emplacement. A younger cluster of concordant data points at $1844 \pm 15 \mathrm{Ma}$ is interpreted as the age of metamorphic overprint.

\section{Sample 12: Foliated granodiorite (CB-5063-A13; LA- ICPMS)}

Sample 12 is from a magnetite-bearing, foliated granodioritic layer in a generally felsic to intermediate orthogneiss that is part of the Simitalik Suite in the Falcoz River Block. It contains abundant colourless to dark brown equant to elongate zircon prisms with predominantly rounded to subrounded terminations. Crystals range in length from $10-150 \mu \mathrm{m}$ and 10 $100 \mu \mathrm{m}$ in width. CL zoning in shades of blue, grey, and pale yellow is mostly planar with local patchy zoning with a subset of crystals exhibiting oscillatory zoned blue-grey cores with featureless overgrowths. Most analyses define a single cluster on a Concordia diagram (Fig. 8F), yielding a calculated age of $2835 \pm 6 \mathrm{Ma}$, interpreted as the age of emplacement.

\section{Sample 13: Enderbitic Gneiss (IL-3157-A13; LA-ICPMS)}

Sample 13 is from an enderbitic gneiss from the eastern part of the Falcoz River Block. It contains abundant colourless to pale brown zircon ranging from 50-200 $\mu \mathrm{m}$ in length and 50 $70 \mu \mathrm{m}$ wide. Optical CL imaging revealed a combination of 
simple concentric oscillatory zoning with colours ranging from blue to grey to pale yellow. A few grains display oscillatoryzoned cores that are truncated by thin $(10-20 \mu \mathrm{m})$ discontinuous overgrowths typically with pale yellow CL. Domains of more nebulous transgressive recrystallization that partially obscure oscillatory-zoned cores are also locally visible. The 24 $\mu \mathrm{m}$ laser craters were located wherever possible on subdomains where primary oscillatory zoning features were preserved, although some analyses were placed completely within overgrowth domains that yielded younger concordant ages. The U-Pb data for this sample (LA-ICPMS) display a combination of recent and ancient $\mathrm{Pb}$ loss as well as the effects of small and variable common- $\mathrm{Pb}$ incorporation (Fig. 9A). In order to avoid effects of common- $\mathrm{Pb}$ incorporation, the data were filtered to consider only analyses that encountered $>98 \%$ $\mathrm{Pb}^{*}$ (as estimated using the Andersen (2002) routine in VizualAge) as well as ${ }^{206} \mathrm{Pbcps} /{ }^{204} \mathrm{Pbcps}>1000$. This yielded a subset of data that defines a statistically robust $($ MSWD $=1.7$ ) discordia with an upper intercept of $2883 \pm 12 \mathrm{Ma}$ and a lower intercept of $1768 \pm 52 \mathrm{Ma}$. The existence of a single concordant $2040 \pm 13 \mathrm{Ma}$ overgrowth $\left({ }^{207} \mathrm{~Pb} /{ }^{235} \mathrm{U}\right.$ age) hints at possible older reworking of this sample.

\section{Sample 14: Massive Enderbite (BC-6179-A13: LA-ICPMS)}

Sample 14 from massive enderbite contains sparse colourless to pale-brown stubby to elongate zircon prisms with rounded terminations. The grains are typically $40-60 \mu \mathrm{m}$ wide and 100 $200 \mu \mathrm{m}$ long. A large number of the grains are fractured and a few contain small cores observable in transmitted light. Optical CL imaging revealed a diversity of CL intensities and internal zoning features with primarily dark-blue (higher $\mathrm{U}$ ), paleblue, grey, and pale-yellow colours. Zoning is primarily planar with rare concentric oscillatory zoning. Patchy transgressive zoning that truncates planar and oscillatory zones is also locally present.

The U-Pb data for this sample display evidence for ancient $\mathrm{Pb}-$ loss and possibly physical mixing between two older endmembers. The evidence for mixing comes from a continuous array of near-concordant data points between $\sim 2832 \pm 21 \mathrm{Ma}$ and $2661 \pm 9 \mathrm{Ma}$ and that for Pb-loss from the series of discordant analyses trending towards a lower intercept of $1808 \pm$ $86 \mathrm{Ma}$ (see Fig. 9B). These patterns are best interpreted as caused by mixed sampling, with the laser crater straddling ca. $2830 \mathrm{Ma}$ domains representing inherited cores, and ca. 2660 Ma domains representing zones of crystallization.

\section{Sample 15: Tonalitic Gneiss (SB-4161-A13; LA-ICPMS)}

Sample 15 from tonalitic gneiss contains abundant elongate $(\sim 60 \mu \mathrm{m} \times \sim 200 \mu \mathrm{m})$, colourless to pale brown zircons with subrounded terminations. The majority of grains produced minimal CL response in shades of dark blue. A few colourless grains produced CL that revealed a combination of simple planar zoning and concentric oscillatory zoning. A few of the grains display small high-U cores marked by more severe radiation damage (reddish-brown zones) in the neighbouring overgrowths.
The U-Pb data for these highly radiogenic zircon grains form a discordant array between $\sim 2650 \mathrm{Ma}$ and $\sim 1800 \mathrm{Ma}$ (Fig. 9C). Data points with $>99 \% \mathrm{~Pb}^{*}$ define a line (as a result of either physical mixing or ancient Pb-loss) with an upper intercept of $2622 \pm 15 \mathrm{Ma}$ (Fig. 9D), interpreted as the age of emplacement, and a lower intercept of $1718 \pm 98 \mathrm{Ma}$ interpreted as the approximate timing of metamorphism.

\section{Mistinibi-Raude Block}

Apart from the ca. 2.33 Ga age reported from Girard (1990a), there are no other $\mathrm{U}-\mathrm{Pb}$ geochronological data reported in the literature for this block. Furthermore, the data for the abovementioned age are not published, with only the interpreted age reported. In order to test that age, as well as provide information on the age and evolution of the Mistinibi-Raude Block in general, four rocks were sampled for $\mathrm{U}-\mathrm{Pb}$ dating including: i) a plagioclase-hornblende porphyry sub-volcanic rock of intermediate composition that intrudes the Ntshuku supracrustal rocks (Sample 16), ii) a K-feldspar megacrystic monzogranite from a suite that intrudes the Ntshuku supracrustal rocks (Sample 17), iii) a granophyre from the Pelland alkaline intrusion (Sample 18), and iv) meta-arkose from the Hutte Sauvage Group (Sample 19).

\section{Sample 16: Plagioclase-Hornblende Porphyry Intrusion, Ntshuku Suite (14CXA-D94A1; SHRIMP)}

Sample 16 is from a 2-m-thick, hornblende-bearing, feldspar porphyry sill intruding mafic volcanic and meta-sedimentary rocks of the Ntshuku volcanic belt. It is interpreted as a subvolcanic intrusion, hence its age should provide a minimum (and also approximate) age for the evolution of the volcanic belt. Zircons from this rock consist mostly of clear, colourless, mildly fractured stubby to elongate prisms with diffuse igneous zoning and subordinate, clear, subrounded, faintly zoned to unzoned grains. Many zircon grains have thin to thick overgrowths, most of which are devoid of zoning. Fifteen $\mathrm{U}-\mathrm{Pb}$ SHRIMP analyses from oscillatory-zoned prisms (Fig. 9E, inset, grain 118) give a weighted mean age of $2373 \pm 7 \mathrm{Ma}$ $(\mathrm{MSWD}=2.1 ; \mathrm{POF}=0.011)$, interpreted as the crystallization age of the porphyry. The two youngest analyses from oscillatory-zoned prisms (11306-56.1 and -61.1) are interpreted to have experienced $\mathrm{Pb}-\mathrm{loss}$ and were excluded from the weighted mean calculation. Faintly zoned rims and subrounded grains yield distinctly younger ages with a weighted mean age of $2317 \pm 8 \mathrm{Ma}(\mathrm{n}=9$; MSWD $=0.74$; POF $=0.66)$, which is interpreted as the time of metamorphic recrystallization. The oldest analysis from this zircon rim population (1130626.2), not included in the mean age calculation, may reflect incomplete recrystallization as a result of the younger overprint event. There are no hints of inheritance or zircon cores, suggesting that the Ntshuku supracrustal belt may be juvenile. Interestingly, there are no hints of New Quebec or Torngat Orogen (i.e. ca. 1.87-1.80 Ga) metamorphic rims either, despite the rock having a moderately strong foliation parallel to the regional N-S fabrics. 
A
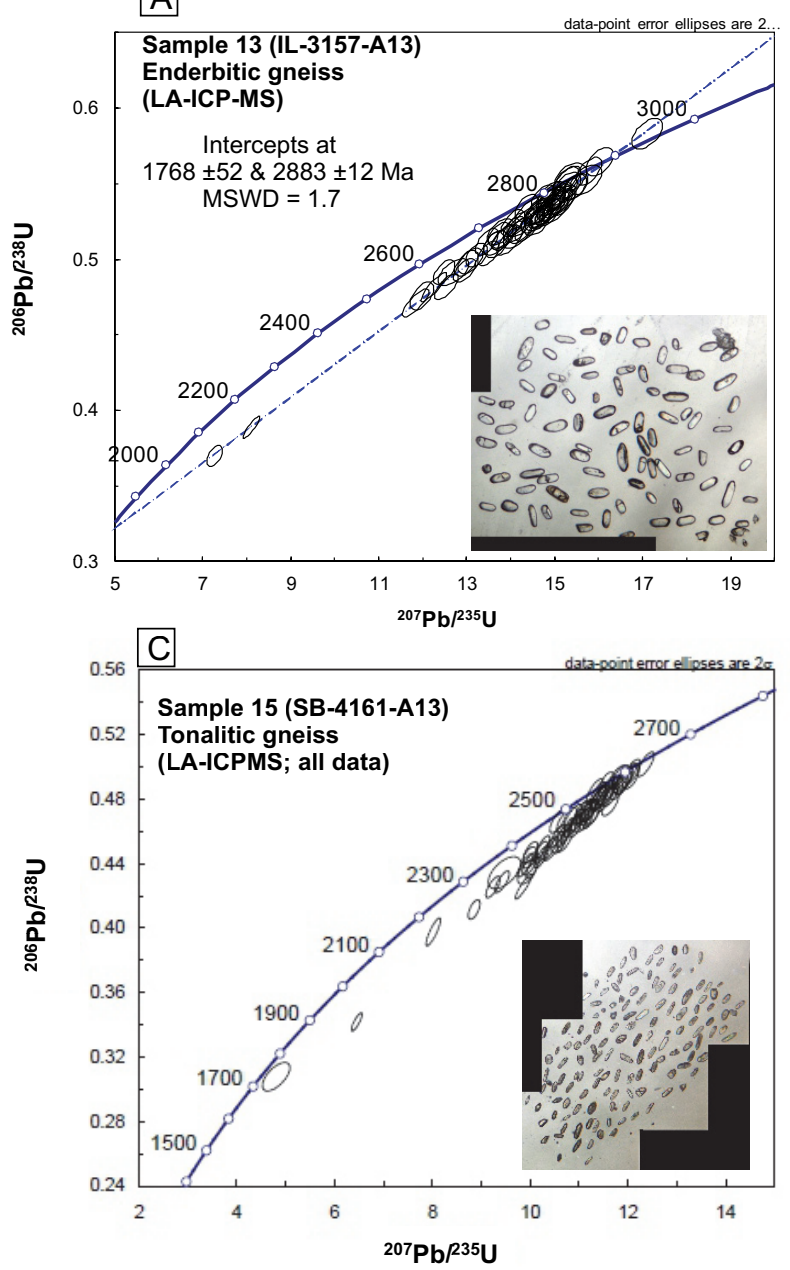

E

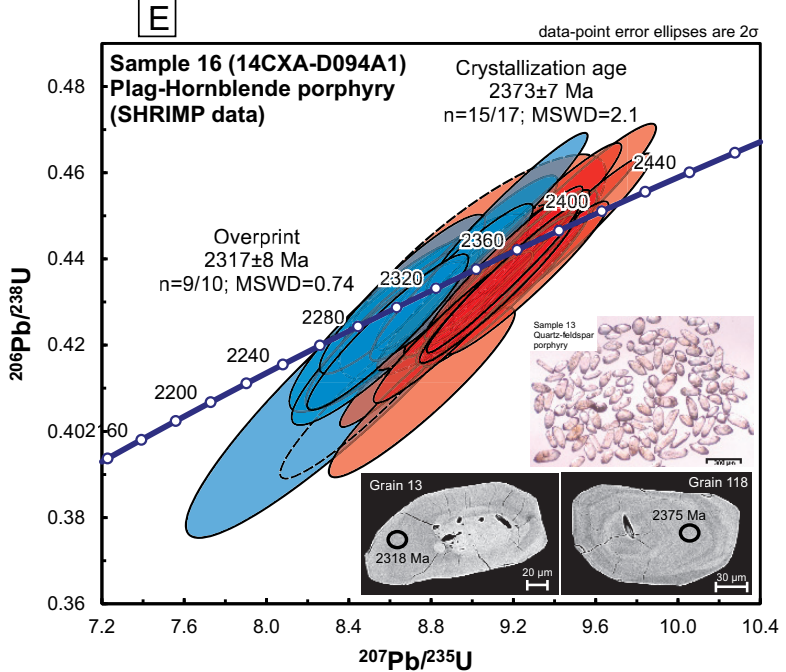

B
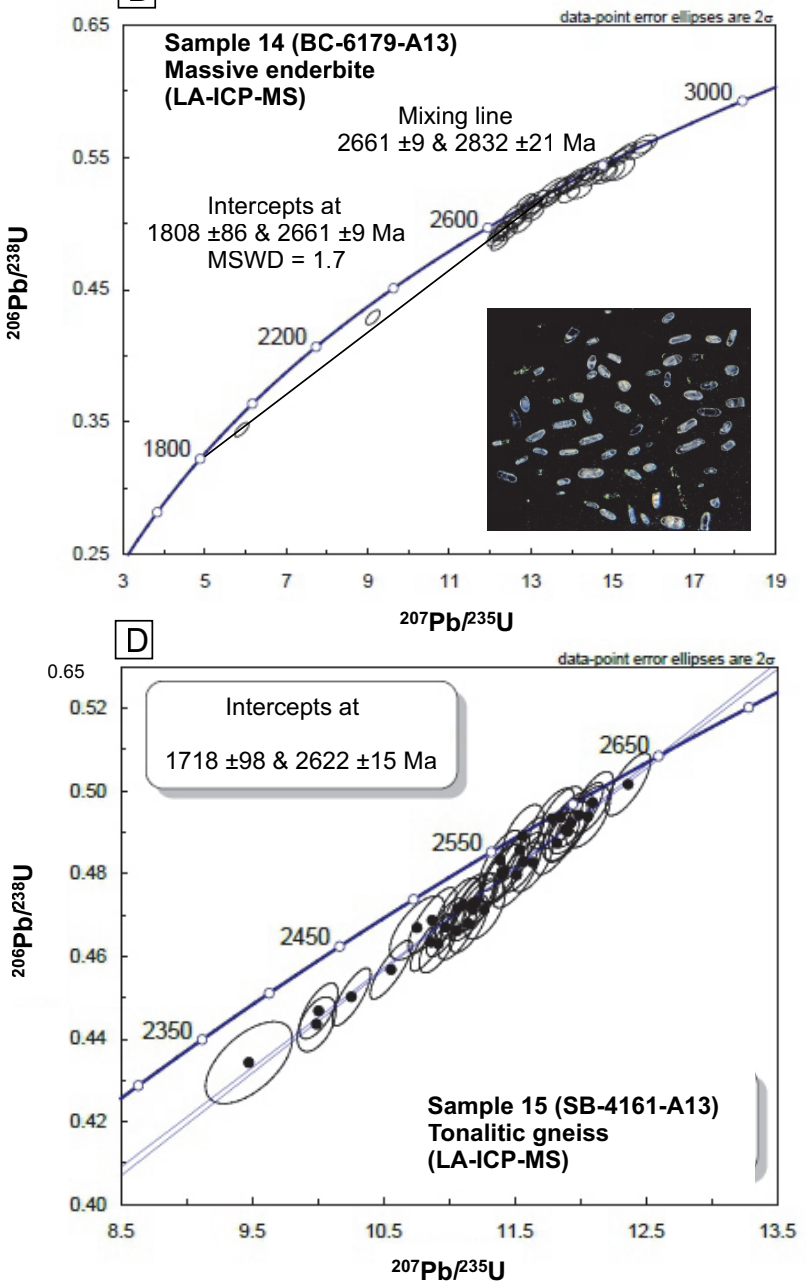

F

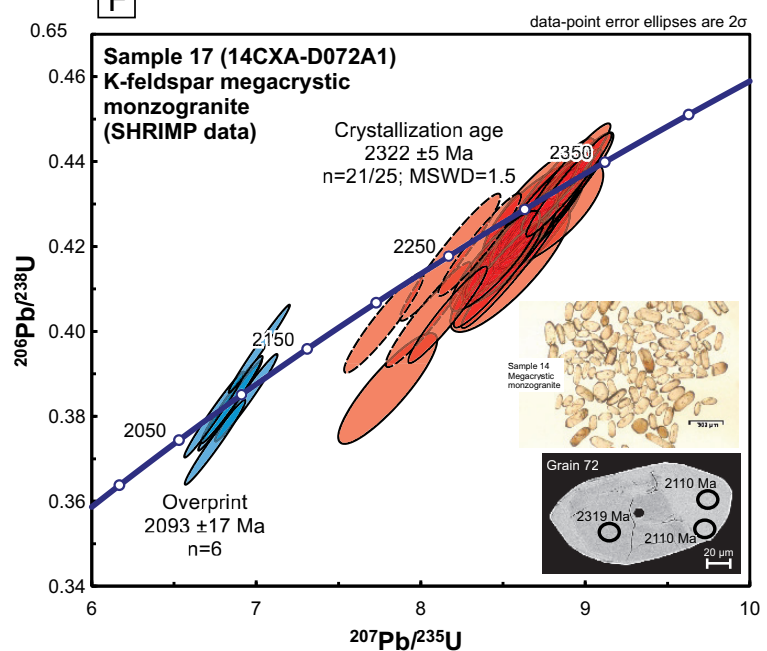

Figure 9. Concordia diagrams ( $2 \sigma$ errors), transmitted light images of zircon, and/or BSE SEM images of representative zircon crystals for rock units from the Falcoz River and Mistinibi-Raude blocks. A) LA-ICP-MS data for Sample 13, an enderbitic gneiss from the Falcoz River Block; B) LA-ICP-MS data for Sample 14, a massive enderbite from the Falcoz River Block. Cathodo-luminescence image of zircons in inset; C) LA-ICP-MS data for granite Sample 15, a tonalitic gneiss from the Falcoz River Block; D) more detailed view of the upper data grouping on the Concordia plot for Sample 15; E) SHRIMP data for Sample 16, a sub-volcanic plagioclase-hornblende porphyry intrusion in the Ntshuku volcanic belt of the Mistinibi-Raude Block; F) SHRIMP data for Sample 17, a K-feldspar megacrystic monzogranite intruding orthogneiss in the MistinibiRaude Block. In the SHRIMP Concordia diagram, red ellipses correspond to analyses from magmatic zircon and blue ellipses to recrystallized or newly grown zircon. Dashed ellipses not included in weighted mean age calculations. In the BSE SEM image, circles indicate approximate location of analyses with corresponding ${ }^{207} \mathrm{~Pb} /{ }^{206} \mathrm{~Pb}$ ages. 


\section{Sample 17: K-feldspar Megacrystic Monzogranite, Pel- land Pluton (14CXA-D72A1: SHRIMP)}

Sample 17 is from one of a series of $\mathrm{K}$-feldspar megacrystic granitoid bodies that have intruded the Ntshuku supracrustal belt, but are for the most part foliated and recrystallized. The monzogranite contains clear, light brown, faintly zoned, stubby to elongate zircon prisms. Medium-brown rims and subequant grains, characterized by a bright BSE response, are also present. The zoned prisms yield a grouping of concordant to near-concordant data points between 2339 and $2231 \mathrm{Ma}$. The 21 oldest analyses from this population define a weighted mean age of $2322 \pm 5 \mathrm{Ma}(\mathrm{n}=21 / 25 ; \mathrm{MSWD}=1.5, \mathrm{POF}=$ 0.063), interpreted as the age of crystallization (Fig. 9F). Analyses from bright unzoned rims have high U concentrations (857-1855 ppm) and their individual dates are very precise. Thus, a robust Tukey's biweight mean calculation was used to minimize the effects of any outliers. The resulting age, $2093 \pm 17 \mathrm{Ma}$, is interpreted as the age of a metamorphic overprint. It is noteworthy that the age of emplacement of this plutonic suite is within error of the metamorphic age obtained for the Ntshuku Belt (see Sample 16), suggesting that plutonism was accompanied by regional deformation and metamorphism within the Mistinibi-Raude Block.

\section{Sample 18: Granophyric Gabbro from the Pelland Pluton (14CXA-D68B1; SHRIMP)}

The Pelland pluton is a composite body consisting of metagabbro, monzodiorite, monzonite, and syenite, and is distinguished by the presence of blue rutilated quartz, rapakivi feldspar, and orthopyroxene-bearing pegmatite, all suggestive of high-temperature, and at least partially anhydrous, conditions during emplacement. The sample dated is from a marginal, granophyric phase of a gabbro containing rare K-feldspar megacrysts and blue quartz. Zircon grains from this sample form stubby to elongated prisms, many with rounded edges and terminations. Core-rim relationships are visible in a number of grains in transmitted light. The distribution of ages from unzoned and oscillatory-zoned zircon between $\sim 2050$ and $2370 \mathrm{Ma}$ does not permit an unambiguous age interpretation (Fig. 10A). Nonetheless, the four youngest analyses from homogeneous rims and grains yield a weighted mean ${ }^{207} \mathrm{~Pb} /{ }^{206} \mathrm{~Pb}$ age of $2053 \pm 13 \mathrm{Ma}(\mathrm{MSWD}=1.16, \mathrm{POF}=0.32)$, interpreted as the age of metamorphism of the gabbro. Oscillatory-zoned zircons plot along Concordia from the metamorphic age to $2.37 \mathrm{Ga}$. The nine oldest analyses exhibit excess scatter with a weighted mean age of $2339 \pm 22 \mathrm{Ma}$ and MSWD of 6.5. The Tukey biweight mean age for these analyses, 2320 $\pm 21 \mathrm{Ma}$, overlaps with the weighted mean age and is taken as a more robust estimate of the age of the rock. However, given evidence for extensive Pb-loss in this zircon population as a result of the younger metamorphic event, this age should be regarded as a minimum estimate of the crystallization of the granophyric gabbro. The oldest analyses are from faintly zoned cores or grains that are interpreted as inherited. Their ${ }^{207} \mathrm{~Pb} /{ }^{206} \mathrm{~Pb}$ ages, which range from $\sim 2350$ to $2500 \mathrm{Ma}$, are interpreted as representing the approximate or minimum age of crust assimilated into the granophyric, marginal phase of the gabbro, again suggesting that the Mistinibi-Raude Block is principally juvenile as is the case with samples 16 and 17 above.

\section{Sample 19: Meta-Arkose, Hutte Sauvage Group (14CXA- D18A1; SHRIMP)}

The Hutte Sauvage Group unconformably overlies the Ntshuku and Mistinibi belts. It consists of matrix-supported pebble to cobble conglomerate at the base, grading upwards to meta-arkosic sandstone. The sample dated is from the upper part of the section, within a meta-arkosic layer containing trough crossbeds outlined by heavy mineral layers. Zircon from the meta-arkose consist of colourless to pale brown prisms or subequant crystals. Many grains preserve facets and terminations, but a small number show evidence for mechanical abrasion. Sixty five SHRIMP analyses were carried out on 61separate zircon grains, yielding dates between 2570 and 1978 Ma (Figs. 10B and 10C). All results are within $\pm 5 \%$ discordance and therefore considered to approximate the true crystallization ages of the zircon grains. The detrital provenance profile is characterized by three dominant modes at ca. 2510 Ma, ca. $2320 \mathrm{Ma}$, and ca. $2080 \mathrm{Ma}$. Replicate analyses on the youngest detrital zircon (grain 10) yield a weighted mean age of $1987 \pm 7 \mathrm{Ma}(\mathrm{n}=5 / 5 ; \mathrm{MSWD}=1.01, \mathrm{POF}=0.40)$, interpreted as the maximum age of deposition. Based on the three dominant modes, it is noteworthy that all detrital zircon grains appear to have been derived solely from the Mistinibi-Raude Block and have not sourced adjacent Archean domains. This dataset also provides constraints that do not support incorporation of detritus from the De Pas Batholith into the Hutte Sauvage Group, an interpretation made earlier based on the presence of K-feldspar megacrystic granite cobbles (Girard 1990a).

\section{Lac Lomier Complex}

The Lac Lomier Complex consists mainly of banded, granulite-facies orthogneiss ranging from mafic to felsic but of predominantly intermediate (enderbitic) composition. The complex locally hosts elongate map-scale ribbons or screens of metapelitic rock interpreted as fragments of the Tasiuyak accretionary wedge incorporated into the Lac Lomier continental magmatic arc during its emplacement (Wardle et al. 2002). U-Pb zircon data from the Lac Lomier Complex has been proven difficult to interpret, since its lower crustal emplacement under granulite-facies metamorphism have brought into question whether the dated zircon are igneous or metamorphic. An age of ca. $1.86 \mathrm{Ga}$ has been generally attributed to emplacement (Wardle and van Kranendonk 1996). We have collected a sample to try to clarify that issue by analysing cores and rims with the SHRIMP method.

\section{Sample 20: Monzogranite (14CXA-D30C2; SHRIMP)}

The dated Sample 20 is from a highly strained, monzogranite dyke emplaced in ultra-high P-T metapelite assumed to belong to the Tasiuyak gneiss. The dyke is transposed into sub-parallelism with the metapelite, but has clearly intruded it. Zircon from this sample occurs mostly as clear, colourless to pale brown rounded crystals or anhedral fragments. Prismatic 
A
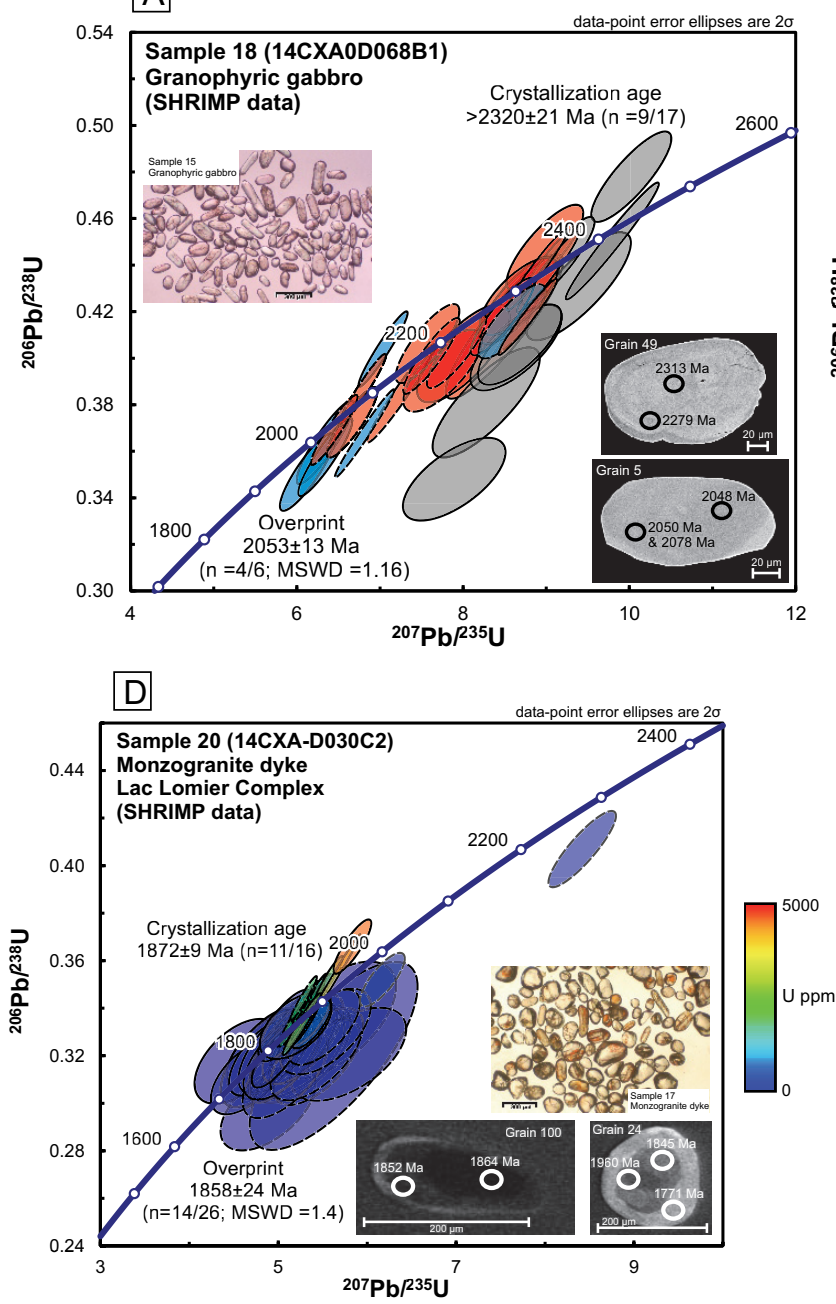

B
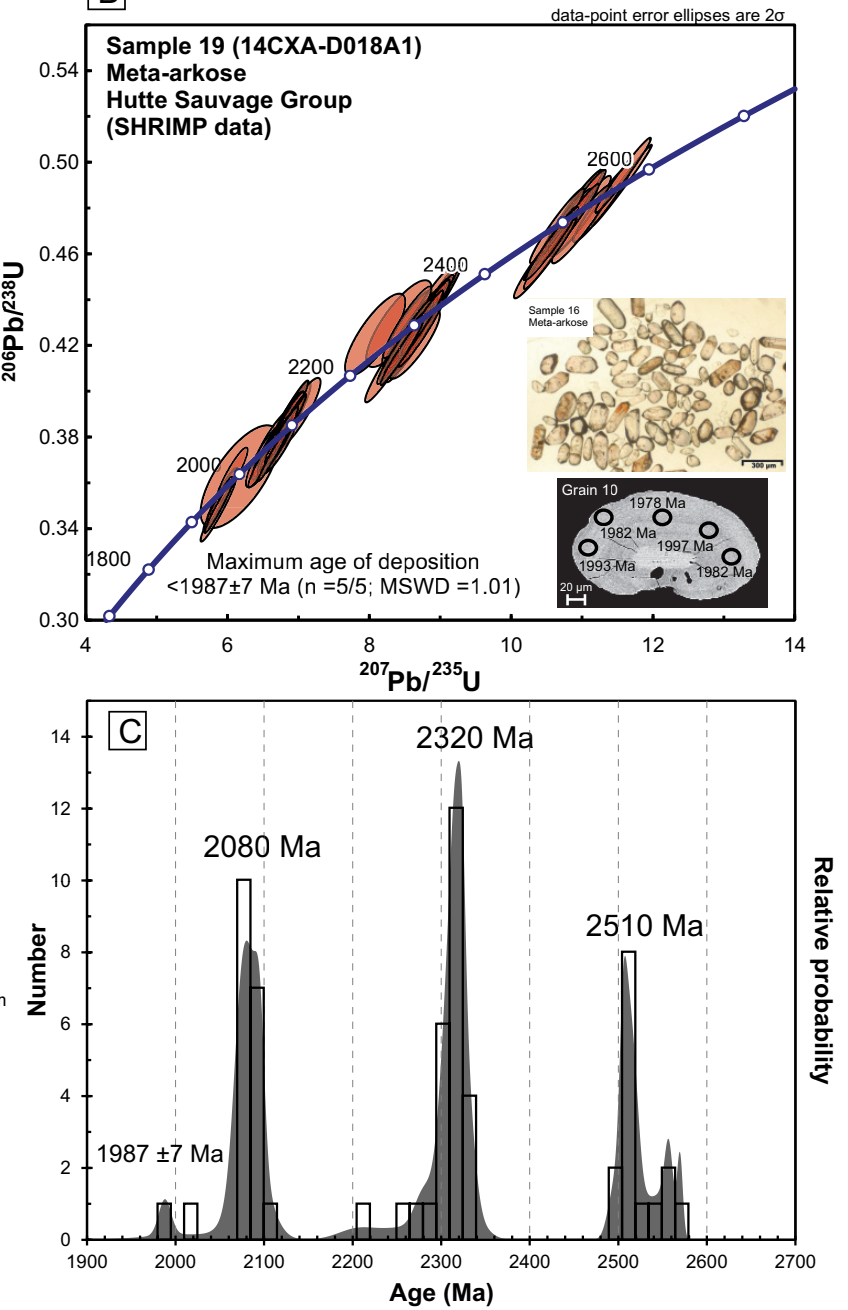

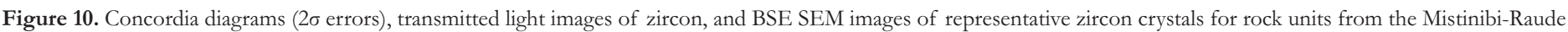

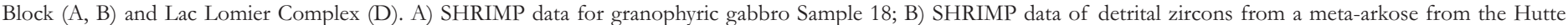

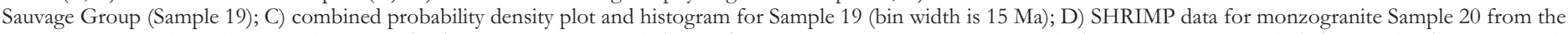

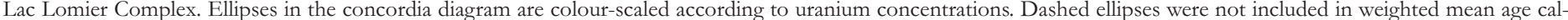

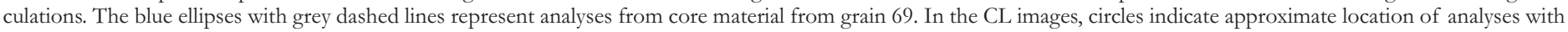
corresponding ${ }^{207} \mathrm{~Pb} /{ }^{206} \mathrm{~Pb}$ ages.

grains are also present, but are strongly resorbed with no preserved facets, crystal edges or terminations. Rounded crystals and anhedral fragments predominantly display medium to high CL response with sector or irregular zoning, whereas most prisms are characterized by very low CL response (dark) with rare broad zoning. Bright CL rims surrounding darker cores are present in all morphological types. The SHRIMP data define two compositionally distinct groupings (Fig. 10D), which broadly correlate with grain morphology. The 11 oldest analyses from dominantly prismatic grains with high $U$ concentrations (526-4742 $\mathrm{ppm}$ ) and generally low but variable $\mathrm{Th} / \mathrm{U}$ ratios (0.01-0.70) yield a Tukey's biweight mean age of $1872 \pm 9 \mathrm{Ma}(\mathrm{n}=11 / 16)$. The very low Th/U ratios from this population are consistent with metamorphic growth; however, the prismatic shape of the grains is more consistent with magmatic growth. Thus, based on this morphological evidence, we interpret the $1872 \pm 9 \mathrm{Ma}$ as the age of crystallization of the monzogranite dyke. Analyses derived from rounded crystals, anhedral fragments, and rims with a medium to high CL response are characterized by distinctly lower $\mathrm{U}$ concentrations (26-293 ppm), higher Th/U ratios (1.02-2.70), and highly variable ${ }^{207} \mathrm{~Pb} /{ }^{206} \mathrm{~Pb}$ ages ranging from 2110 to $1691 \mathrm{Ma}$. Fourteen of the fifteen youngest analyses from this population give a weighted mean age of $1858 \pm 24 \mathrm{Ma}$ ( 1 of 15 rejected; MSWD $=1.4, \mathrm{POF}=0.16)$. The rejected analysis is the youngest in the group at $1691 \pm 68 \mathrm{Ma}$. Based on morphology, zoning characteristics, and chemistry, this age is assigned as the time of metamorphism. The older analyses from this grouping (1922$2110 \mathrm{Ma}$ ) are highly discordant $(>6 \%)$ and may include an inherited component. Two low- $\mathrm{U}$ analyses from the core of prismatic grain 69 with non-reproducible ${ }^{207} \mathrm{~Pb} /{ }^{206} \mathrm{~Pb}$ ages of 2345 and $2058 \mathrm{Ma}$ also likely reflect inheritance. The host 
metapelite could be the source of the 1922-2345 Ma zircon, but these dates should be taken as minimum ages of inheritance given the strong discordancy of the data.

\section{DISCUSSION}

The data presented here as well as reported in the literature, together with field observations and recent mapping, suggest that the Core Zone consists of at least three distinct crustal blocks separated by ductile, sub-vertical shear zones that could potentially represent ancient sutures. We define them here as the George River Block, the Mistinibi-Raude Block, and the Falcoz River Block. Also, we exclude the Kuujjuaq Domain and Lac Lomier Complex from the Core Zone sensu stricto. The Kuujjuaq Domain has been interpreted as the uplifted and tectonically reactivated margin of the Superior Craton (Wardle et al. 2002; Rayner et al. 2017). The Lac Lomier Complex is the root of a 1.87-1.86 Ga continental magmatic arc emplaced along the western accretionary margin of the Nain Craton and it is in structural relationship with the Core Zone. While acknowledging the previous domain nomenclature, we introduce some new nomenclature in an attempt to bring uniformity and consistency throughout the region. In addressing this issue, we have generally considered priority and opted for the first published use of names for a particular crustal block or domain, or by grouping previous sub-domains if warranted by the $\mathrm{U}-\mathrm{Pb}$ zircon data presented herein.

The George River Block consists of remnants of a Neoarchean terrane that comprises juvenile ca. 2.73 to $2.70 \mathrm{Ga}$ supracrustal rocks (Tunulik Belt) and their plutonic root, with the latter including mainly felsic and intermediate composition intrusions that have yielded ages as young as $2568 \pm 5 \mathrm{Ma}$. It is bounded to the west by the Lac Tudor shear zone, and to the east by the George River shear zone. The George River Block is the primary host of the ca. 1.84-1.82 Ga De Pas Batholith, although it is clear that $\mathrm{K}$-feldspar megacrystic intrusions of similar age and composition also occur within the Kuujjuaq Domain to the west (i.e. Sample 8). There has been some debate as to whether the De Pas Batholith represents a continental magmatic arc, as suggested by Dunphy and Skulski (1996), or a syn-collisional magmatic suite (i.e. Wardle et al. 2002). We consider the common presence of hornblende and titanite as well as the absence of any significant volume of contemporaneous S-type magmas to be more suggestive of an arc derivation. The Lac Tudor shear zone has traditionally been interpreted as the ancient suture, where presumably eastdipping subduction of oceanic lithosphere would have generated the De Pas batholith (e.g. Wardle et al. 2002). However, our identification of rocks of similar composition and age to the De Pas suite in the Kuujjuaq Domain, west of the Lac Tudor shear zone, challenges that interpretation. Our current understanding of the distribution of De Pas age plutons would require either a single, west-directed subduction along the eastern margin of the George River Block (suture situated along the George River shear zone), or a divergent double subduction (e.g. Soesoo et al. 1997) situated along the Lac Tudor shear zone. We note that the divergent double subduction model is attractive inasmuch as it potentially involves slab floundering, which could account for the large volume of mantle-derived melt, a large portion of it having been emplaced at high temperatures under anhydrous conditions.

Farther south, the George River Block continues into the Crossroads and Orma domains (Fig. 1) identified by James et al. (2003). The Orma Domain hosts supracrustal rocks (Zeni Complex) that can be traced northwards on aeromagnetic maps and appear to merge with the Tunulik Belt. It also hosts metaplutonic rocks ranging in age from 2628 to $2581 \mathrm{Ma}$, similar in range to the 2648-2568 Ma intrusive rocks in the George River Block as determined herein. We therefore include the Crossroads and Orma domains in the George River Block, which thus extends from the Grenville Front north to Ungava Bay (Fig. 2).

The Mistinibi-Raude Block, which is separated from the George River Block by the George River shear zone and from the Falcoz River Block by the Moonbase shear zone, comprises crust formed at ca. 2.37-2.32 $\mathrm{Ga}$ and thus represents a unique component of the Core Zone. Moreover, from a global crustal growth perspective (e.g. Condie et al. 2009) it also forms a relatively rare fragment of arc-derived volcanic and plutonic rocks of earliest-Paleoproterozoic age, a period not well represented in the geological record. The oldest recognized component of the block, the predominantly mafic volcanic Ntshuku Belt, has not been directly dated as we have not been successful at finding zircon-bearing volcanic protoliths. However, a plagioclase-hornblende porphyry sill of intermediate composition that we interpret as a sub-volcanic intrusion, provides a minimum age for volcanism of $2373 \pm 7 \mathrm{Ma}$. The supracrustal rocks of the Ntshuku Belt are intruded by a suite of mafic to felsic plutonic rocks of arc affinity, previously dated at ca. $2.33 \mathrm{Ga}$ (Pallatin suite; age cited in Girard 1990a). We provide two new ages for plutonic units that confirm the existence of a substantial volume of plutonic rocks of that age-range. These are the Pelland pluton, for which a poorly defined age of ca. $2320 \pm 21$ Ma provides an approximate emplacement age (Sample 18), and a K-feldspar megacrystic monzogranite dated at $2322 \pm 5 \mathrm{Ma}$ (Sample 17). The Pelland pluton is composed of quartz-poor, mafic to alkaline intrusions that crystallized at very high temperatures, as suggested by the presence of rutilated quartz, hypersolvus feldspars and locally, orthopyroxene. A similar but yet undated suite (Nekuashu pluton) occurs about $25 \mathrm{~km}$ to the northwest of the Pelland intrusion. Zircons from the ca. 2.37 Ga subvolcanic intrusion (Sample 16) show evidence for metamorphism at ca. $2.32 \mathrm{Ga}$ that can be broadly correlated to emplacement of the Pallatin and Pelland intrusions. The latter two, in turn, show evidence for metamorphic zircon growth at ca. 2.09$2.05 \mathrm{Ga}$, a feature that appears to be unique to the MistinibiRaude Block. The Hutte Sauvage meta-arkose, which appears to have sourced zircon uniquely from the Mistinibi-Raude Block, does not contain zircon derived from the $\geq 2.73 \mathrm{Ga}$ Ntshuku volcanic rocks, but contains abundant zircon from the ca. $2.32 \mathrm{Ga}$ intrusions. Interestingly, it contains an older population of detrital zircon as well, with a peak age of ca. $2.50 \mathrm{Ga}$ and for which no local equivalents have yet been found in outcrop, either in the Mistinibi-Raude or adjacent 
blocks. We assume that zircon of that age represent older crust onto which the Ntshuku supercrustal rocks were erupted and deposited, and provide an upper age limit for the MistinibiRaude Block. Based on geochemical studies, Girard (1990b, c) suggested an immature arc setting for the Ntshuku volcanic rocks and related intrusions.

The large expanse of crust situated east and northeast of the George River and Mistinibi-Raude blocks, previously subdivided into four domains, is herein amalgamated into the Fal$\mathrm{CO}$ River Block. Along its western flank, the Falcoz River Block is separated from the George River and Mistinibi-Raude blocks by the George River and Moonbase shear zones. Along its eastern flank it is separated from the 1.87-1.86 Ga Lac Lomier Complex by the Abloviak and Falcoz shear zones (Fig. 2), two features that appear to anastomose with one another, and also enclose lenses of less strained crust. In the northern reaches of the map area, the Falcoz shear zone eventually splays from the Abloviak shear zone and can be traced some distance northwestwards towards Ungava Bay, where it loses definition. A feature common to the four former domains now amalgamated into the Falcoz River Block is the widespread presence of tonalitic to granitic gneiss and migmatite (tonalitetrondjemite-granite association), the oldest of which have yielded U-Pb crystallization ages of ca. $2856 \pm 8 \mathrm{Ma}$ and 2883 $\pm 12 \mathrm{Ma}$ (samples 9 and 13, respectively). However, other dated protoliths are distinctively younger, yielding $\mathrm{U}-\mathrm{Pb}$ zircon ages of $2835 \pm 6 \mathrm{Ma}, 2670 \pm 14 \mathrm{Ma}, 2661 \pm 9 \mathrm{Ma}$ and $2622 \pm 15$ $\mathrm{Ma}$ (samples 12,11, 14 and 15, respectively), suggesting successively younger pulses of felsic to intermediate magmatism. The $2796 \pm 29 \mathrm{Ma}$ age is within error of a $2807+45 /-27 \mathrm{Ma}$ age obtained by Ryan et al. (1991) for a tonalitic gneiss from the southeastern part of the Falcoz River Block. Moreover, Ryan et al. (1991) also dated granitoid rocks ranging in age from ca. $2657 \pm 18$ to $2574 \pm 8 \mathrm{Ma}$ from the same area, suggesting an increase in the proportion of Neoarchean igneous rocks towards the southeast. Along its western flank, the Fal$\mathrm{COz}$ River Block is separated from the George River and Mistinibi-Raude blocks by the George River shear zone and Moonbase shear zone, respectively (Fig. 3). From a metamorphic perspective, the Falcoz River Block comprises granulite-facies assemblages along its eastern half, adjacent to the Lac Lomier Complex, and mainly upper-amphibolite facies assemblages in its northwestern part (see Fig. 2). It also preserves more Paleoproterozoic supracrustal cover rocks in its northern extents. There is definitely a Proterozoic-age granulite facies event, as is implied from metamorphic assemblages present in the cover rocks. However, it is also possible that Archean-age metamorphism also reached granulite facies, at least locally.

The Tasiuyak gneiss has historically been interpreted as a thick accretionary complex formed during the Torngat Orogeny and is intruded by the 1.87-1.86 Ga Lac Lomier continental arc (Wardle et al. 1990; Wardle and van Kranendonk 1996). At the location of Sample 20, a large enclave of granulite-facies metapelite, interpreted as a raft of Tasiuyak gneiss within the Lac Lomier Complex, is intruded by a 2 -m-thick monzogranite dyke, dated herein at $1872 \pm 9 \mathrm{Ma}$. The monzogranite dyke is presumably an offshoot of the main Lac Lomier Complex and both it and its host metapelite were strongly transposed within the Abloviak shear zone and, hence, the $1858 \pm 24$ Ma metamorphic age obtained from this sample (Fig. 10D) provides an estimate for the timing of shearing. However, in detail, the actual metamorphic history appears to be relatively more complex as suggested by the spread of metamorphic age data (i.e. see grain 24, Fig. 10D inset, with spots as young as ca. 1.77 $\mathrm{Ga}$ ), suggesting that the Abloviak shear zone may have been a long-lived feature. Other small map units of Paleoproterozoic cover sequences composed of high-grade metapelite that occur throughout the mid- to northern Falcoz River Block are more likely related to the Lake Harbour Group than to the Tasiuyak gneiss (Scott et al. 2002, but see discussion below). East of the Tasiuyak gneiss lies the Nain Province, an ancient crustal block that forms part of the North Atlantic Craton. It is composed of two main blocks, the ca. 3.0-3.2 Ga Hopedale Block to the south, and the 3.0-3.8 Ga Saglek Block to the north (James et al. 2002). Both these blocks are significantly older than the Falcoz River Block, suggesting that there is no obvious relation between it and the Nain Province.

\section{"Exotic" Core Zone and Speculations on its Northern Extension}

In light of the previous discussions it is clear that: i) the Core Zone is composed of three distinct Archean to early Paleoproterozoic crustal fragments (shear-zone bounded blocks) with contrasting geologic histories, implying that they developed separately prior to their tectonic juxtaposition in the Core Zone in the Paleoproterozoic, and ii) that all three blocks comprising the Core Zone are apparently exotic with respect to the adjacent Superior and North Atlantic cratons. These relationships cast doubts on (but do not preclude) the former interpretation that the Archean rocks in the Core Zone formed a ribbon continent (James and Dunning 2000). They also provide context for a discussion about the possible correlatives of either George River, Mistinibi-Raude or Falcoz River blocks farther north in the Trans-Hudson Orogen, and more speculatively about their linkages to other cratons that comprised parts of the Nuna supercontinent between ca. 1.90 and 1.80 Ga (Stauffer 1984; Hoffman 1990; Corrigan et al. 2009; Pehrsson et al. 2015). A proposed correlation of the Falcoz River Block with parts of the Meta-Incognita microcontinent (Fig. 1), exposed on the peninsula of the same name on southern Baffin Island (see Jackson and Taylor 1972; Scott and St-Onge 1998; St-Onge et al. 2000; Bourlon et al. 2002) is primarily based on the similarity between Paleoproterozoic quartzitepelite-marble (QPM) associations at both localities. However, the correlation is not entirely unambiguous. In the Falzoz River Block, QPM rocks unconformably sit on ca. 2.9-2.7 Ga Archean basement gneisses and are intruded by minor Paleoproterozoic plutonic rocks of ca. $1.86 \mathrm{Ga}$ age, for which a correlation with the Cumberland Batholith remains to be proven. Both the lack of bona fide Archean basement to the Paleoproterozoic QPM lithologies in the Meta-Incognita microcontinent and their occurrence there in detached slices in a thrust stack, suggest the proposed correlation should be considered tentative at best. On the other hand, although not exposed at 
surface, evidence of Archean crust-forming events of ca. 2.68 $\mathrm{Ga}$ and 2.63-2.60 $\mathrm{Ga}$ with a minor contribution from Mesoarchean crust (ca. 3.00 and $2.85 \mathrm{Ga}$ ) is found in detrital and xenocrystic zircons in QPM and metaplutonic rocks from the Meta-Incognita microcontinent (Wodicka et al. 2010), making a correlation with the Falcoz River Block permissible. In light of the robust confirmation of distinctive, ca. 2.38 and 2.32 Ga plutonic units in the Mistinibi-Raude Block in this study and their rarity in the geological record of the Canadian Shield, perhaps the most compelling evidence that the Core Zone rocks may link with the Meta-Incognita microcontinent is the presence there of detrital and xenocrystic zircon of ca. 2.34-2.31 Ga age, also reported in Wodicka et al. (2010), as well as a $2310 \pm 3 \mathrm{Ma}$ cobble from a deformed and metamorphosed conglomerate reported by Partin et al. (2014). These ages fall within the range determined from the Mistinibi-Raude Block and suggest a possible correlation. Although it could be argued that these Baffin Island zircon ages could represent detrital grains with a Core Zone provenance and not a local basement source, the presence of cobble suggests a proximal source.

Correlation of the George River Block northwards into the Trans-Hudson Orogen is a bit more problematic as there are no known crustal slices of that specific and relatively 'tight' Neoarchean age range $(2.70-2.57 \mathrm{Ga})$ identified in the immediate area north and west of Ungava Bay. Along Hudson Strait, the Superior Craton, or at least its reactivated margin (Kovik antiform), is flanked by the Sugluk Block (Fig. 1) which hosts predominantly 3.2-2.8 Ga Archean crust with Paleoproterozoic intrusions (see Corrigan et al. 2009 and references therein). If any correlation would be proposed for the Sugluk Block, it would more likely involve the Falcoz River Block, which comprises ca. 2.9-2.8 Ga crust that overlaps in age with the latter. However, correlations at this point would be speculative at best due to limited geochronological data available from the Sugluk Block.

Following the same line of investigation farther afield to the southwest across Hudson Bay, reveals other possible correlations. Within the former tract of the ancient Manikewan Ocean that was closed during the Trans-Hudson Orogeny (Stauffer 1984), ca. 2.4-2.5 Ga plutonism has been identified in the Sask Craton (see Bickford et al. 2005 and references therein), located in the Trans-Hudson orogeny internides in what is now central Manitoba and Saskatchewan (Fig. 1). Moreover, ca. 2.3-2.5 Ga detrital zircons have been identified in metagreywacke and as xenocrysts in plutonic rocks within the Trans-Hudson Orogen internides between the Sask and Hearne cratons (Southern Indian Lake area; see Rayner and Corrigan (2004) and Partin et al. (2014)), suggesting the presence of crust of the same age as the Mistinibi-Raude Block in that portion of the orogeny ('SIL' in Figure 1). Hence, there is evidence for the presence of earliest-Paleoproetrozoic crust of ca. 2.5-2.3 Ga age now isolated in distinct crustal slices within a closed paleo-ocean realm west, north and east (present day coordinates) of the Superior Craton. Whether these represent vestiges of a tectonically dismembered, single continental mass remains to be determined. To the northeast towards Green- land, on the other hand, there is no hint of ca. 2.5-2.3 Ga protoliths in the Nagssugtoqidian Orogen (Fig. 1), which is the site of ocean closure and ca. 1.86-1.82 Ga continent-continent collision north of the North Atlantic Craton (van Gool et al. 2002).

\section{Paleoproterozoic Tectonic Evolution and Metamorphism}

In this paper we have presented evidence for the presence of at least three lithologically distinct crustal blocks forming the Core Zone. The ductile shear zones that bound these blocks are steep and locally form an anastomosing array that accommodated bulk dextral transpressional shear via mainly sub-horizontal, transcurrent motion. Wardle and van Kranendonk (1996) and Wardle et al. (2002) speculated that this bulk regional deformation was a result of oblique convergence between the North Atlantic and Superior cratons during the Paleoproterozoic. The distinct chronological and lithological character of the three Core Zone blocks with respect to the bounding Superior and North Atlantic cratons suggests that: i) they formed at different times in completely different environments and are exotic to both the North Atlantic and Superior cratons, and ii) the Lac Tudor, George River, Moonbase and Abloviak shear zones represent paleo-sutures. From a tectonothermal perspective, the George River and Falcoz River blocks bear similar metamorphic age ranges, between ca. 1831 and 1773 $\mathrm{Ma}$ for the former and 1845 and $1768 \mathrm{Ma}$ for the latter (excluding metamorphic ages for samples 14 and 15, which show very large analytical errors), suggesting that they were structurally and metamorphically reactivated during the Paleoproterozoic, particularly during the New Quebec Orogen phase. However, the interior of the Mistinibi-Raude Block, as well as the southeastern extents of the George River Block (Orma Domain of James and Dunning (2000)) appear to have mainly escaped ca. 1.85-1.76 Ga Paleoproterozoic metamorphism. This might be the result of south-directed crustal extrusion and resulting north-to-south extension, a hypothesis that will be discussed in a subsequent publication.

\section{ACKNOWLEDGEMENTS}

This paper stems from a collaboration between the Geological Survey of Canada and the Ministère des ressources naturelles du Québec and was in large part funded by the Geo-mapping for Energy and Minerals (GEM) Program (Natural Resources Canada). The authors wish to acknowledge logistical support from the Polar Continental Shelf Program. Reviews by Toby Rivers and Charlie Gower greatly enhanced the readability and accuracy of the paper and are much appreciated.

\section{REFERENCES}

Andersen, T., 2002, Correction of common lead in U-Pb analyses that do not report ${ }^{204} \mathrm{~Pb}$ : Chemical Geology, v. 192, p. 59-79, https://doi.org/10.1016/S00092541(02)00195-X.

Bickford, M.E., Mock, T.D., Steinhart III, W.E., Collerson, K.D., and Lewry, J.F., 2005, Origin of the Archean Sask craton and its extent within the Trans-Hudson orogen: evidence from $\mathrm{Pb}$ and $\mathrm{Nd}$ isotopic compositions of basement rocks and post-orogenic intrusions: Canadian Journal of Earth Sciences, v. 42, p. 659-684, https://doi.org/10.1139/e04-064.

Bourlon, E., Mareschal, J C., Roest, W.R., and Telmat, H., 2002, Geophysical correlations in the Ungava Bay area: Canadian Journal of Earth Sciences, v. 39, p. 625-637, https://doi.org/10.1139/e01-098

Chiarenzelli, J., Aspler, L., Villeneuve, M., and Lewry, J., 1998, Early Proterozoic evolution of the Saskatchewan craton and its allochthonous cover, Trans-Hudson orogeny: The Journal of Geology, v. 106, p. 247-267, https://doi.org/10.1086/ 516020 . 
Condie, K.C., O’Neill, C., and Aster, R.C., 2009, Evidence and implications for a widespread magmatic shutdown for $250 \mathrm{My}$ on Earth: Earth and Planetary Science Letters, v. 282, p. 294-298, https://doi.org/10.1016/j.epsl.2009.03.033.

Corrigan, D., Pehrsson, S., Wodicka, N., and de Kemp, E., 2009, The Palaeoproterozoic Trans-Hudson Orogen: a prototype of modern accretionary processes, in Murphy, J.B., Keppie, J.D., and Hynes, A.J., eds., Ancient Orogens and Modern Analogues: Geological Society, London, Special Publications, v. 327, p. $457-$ 479, https://doi.org/10.1144/SP327.19.

Corrigan, D., Brouillette, P., Morin, A., Van Rooyen, D., Wodicka, N., Houlé, M.G., Douma, S.L., and Robillard, K., 2015, Report of activities for the Core Zone and bounding orogens: Tectonic framework and mineral potential: Geological Survey of Canada, Open File 7706, 10 p.

Corrigan, D., Van Rooyen, D., Morin, A., Houlé, M.G., and Bédard, M.-P., 2016 Report of activities for the Core Zone and bounding orogens: recent observations from the New Quebec Orogen in the Schefferville area, Quebec and Labrador, GEM-2 Hudson-Ungava Project; Geological Survey of Canada, Open File 8127, 15 p.

Dunphy, J.M., and Skulski, T., 1996, Petrological zonation across the De Pas batholith: a tilted section through a continental arc?, in Wardle, R.J., and Hall, J., compilers, Eastern Canadian Shield Onshore-Offshore Transect (ECSOOT), Report of the 1996 Transect Meeting: The University of British Columbia, Lithoprobe Secretariat, Report 57, p. 44-58.

Emslie, R.F., and Hunt, P.A., 1990, Ages and petrogenetic significance of igneous mangerite-charnockite suites associated with massif anorthosites, Grenville Province: The Journal of Geology, v. 98, p. 213-231, https://doi.org/10.1086/ 629394

Girard, R., 1990a, Évidence d'un magmatisme arc proterozoïque inférieur (2.3 Ga) sur le plateau de la rivière George: Geoscience Canada, v. 17, p. 266-268.

Girard, R., 1990b, Les cisaillements latéraux dans l'arrière-pays des orogènes du Nouveau-Québec et de Torngat : Une revue: Geoscience Canada, v. 17, p. $301-$ 304.

Girard, R., 1990c, Géologie de la région de la rivière Déat: Ministère des ressources naturelles, Québec, MB 90-15, 149 p.

Hajnal, Z., Lewry, J., White, D., Ashton, K., Clowes, R., Stauffer, M., Gyorfi, I., and Takacs, E., 2005, The Sask Craton and Hearne Province margin: seismic reflection studies in the western Trans-Hudson Orogen: Canadian Journal of Earth Sciences, v. 42, p. 403-419, https://doi.org/10.1139/e05-026.

Hammouche, H., Legouix, C., Goutier, J., Dion, C., and Petrella, L., 2011, Géologie de la région du lac Bonaventure: Ministère des ressources naturelles, Québec, RG 2011-03, 37 p.

Hoffman, P.F., 1988, United plates of America, the birth of a craton: Early Proterozoic assembly and growth of Laurentia: Annual Review of Earth and Planetary Science Letters, v. 16, p. 543-603, https://doi.org/10.1146/ annurev.ea.16.050188.002551.

Hoffman, P.F., 1990, Subdivision of the Churchill Province and extent of the TransHudson Orogen, in Lewry, J.F., and Stauffer, M.R., eds., The Early Proterozoic Trans-Hudson Orogen of North America: Geological Association of Canada, Special Paper 37, p. 15-39.

Isnard, H., Parent, M., Bardoux, M., David, J., Gariépy, C., and Stevenson, R.K., $1998, \mathrm{U}-\mathrm{Pb}, \mathrm{Sm}-\mathrm{Nd}$ and $\mathrm{Pb}-\mathrm{Pb}$ isotope geochemistry of the high-grade gneiss assemblages along the southern shore of Ungava Bay, in Wardle, R.J., and Hall, J., compilers, Eastern Canadian Shield Onshore-Offshore Transect (ECSOOT), Report of the 1998 Transect Meeting: The University of British Columbia, Lithoprobe Secretariat, Report 68, p. 67-77.

Isnard, H., Gariépy, C., Stevenson, R.K., and Perreault, S., 1999, New Sm-Nd and $\mathrm{Pb}-\mathrm{Pb}$ isotopic results for rocks of the core zone east of the George River shear zone, in Wardle, R.J., and Hall, J., compilers, Eastern Canadian Shield Onshore-Offshore Transect (ECSOOT), Report of the 1999 Transect Meeting: The University of British Columbia, Lithoprobe Secretariat, Report 73, p. 14-19.

Jackson, G.D., and Taylor, F.C., 1972, Correlation of major Aphebian rock units in the northeastern Canadian Shield: Canadian Journal of Earth Sciences, v. 9, p. 1650-1669, https://doi.org/10.1139/e72-146.

James, D.T., and Dunning, G.R., 2000, U-Pb geochronological constraints for Paleoproterozoic evolution of the Core Zone, southeastern Churchill Province, northeastern Laurentia: Precambrian Research, v. 103, p. 31-54, https://doi.org/10.1016/S0301-9268(00)00074-7.

James, D.T., Connelly, J.N., Wasteneys, H.A., and Kilfoil, G.J., 1996, Paleoproterozoic lithotectonic divisions of the southeastern Churchill Province, western Labrador: Canadian Journal of Earth Sciences, v. 33, p. 216-230, https://doi.org/10.1139/e96-019.

James, D.T., Kamo, S., and Krogh, T., 2002, Evolution of 3.1 and 3.0 Ga volcanic belts and a new thermotectonic model for the Hopedale Block, North Atlantic craton (Canada): Canadian Journal of Earth Sciences, v. 39, p. 687-710, https://doi.org/10.1139/e01-092.

James, D.T., Nunn, G.A.G., Kamo, S., and Kwok, K., 2003, The southeastern Churchill Province revisited: U-Pb geochronology, regional correlations, and the enigmatic Orma Domain: Newfoundland Department of Mines and Energy, Current Research, Geological Survey Report 03-1, p. 35-45

Kerr, A., James, D.T., and Fryer, B.J., 1994, Nd isotopic and geochemical studies in the Labrador shield: a progress report and preliminary data from the Churchill (Rae) Province, in Wardle, R.J., and Hall, J., compilers, Eastern Canadian Shield Onshore-Offshore Transect (ECSOOT), Report of the 1994 Transect Meeting: The University of British Columbia, Lithoprobe Secretariat, Report 45, p. $51-62$.

Lafrance, I., Simard, M., and Bandyayera, D., 2014, Géologie de la region du lac Saffray (SNRC 24G, 24F): Ministère des ressources naturelles, Québec, RG 2014 $02,49 \mathrm{p}$.

Lafrance, I., Bandyayera, D., and Bilodeau, C., 2015, Géologie de la région du lac Henrietta (SNRC 24H): Ministère des Ressources naturelles, Québec, RG 2015 01, $61 \mathrm{p}$.

Lafrance, I., Bandyayera, D., Charrette, B., Bilodeau, C., and David. J., 2016, Géologie de la région du lac Brisson (SNRC 24A): Ministère de l'Énergie et des Ressources naturelles, Québec, RG 2015-05, 61 p.

Lewry, J.F., and Collerson, K.D., 1990, The Trans-Hudson Orogen: extent, subdivisions and problems, in Lewry, J.F., and Stauffer, M.R., eds., The Early Proterozoic Trans-Hudson Orogen of North America: Geological Association of Canada, Special Paper 37, p. 1-14.

Ludwig, K.R., 2003, User's Manual for Isoplot 3.00, A Geochronological Toolkit for Microsoft Excel: Berkeley Geochronology Center Special Publication No. 4, 70 p.

Machado, N., Goulet, N., and Gariépy, C., 1989, U-Pb geochronology of reactivated Archean basement and of Hudsonian metamorphism in the northern Labrador Trough: Canadian Journal of Earth Sciences, v. 26, p. 1-15, https://doi.org/ $10.1139 / \mathrm{e} 89-001$.

Moorhead, J., and Hynes, A., 1990, Nappes in the internal zone of the Labrador Trough: Evidence for major, early NW-vergent basement transport: Geoscience Canada, v. 17, p. 241-244.

Nunn, G.A.G., Heaman, L.M., and Krogh, T.E., 1990, U-Pb geochronological evidence for Archean crust in the continuation of the Rae Province (eastern Churchill Province), Grenville Front Tectonic Zone, Labrador: Geoscience Canada, v. 17, p. 259-265.

Partin, C.A., Bekker, A., Sylvester, P.J., Wodicka, N., Stern, R.A., Chacko, T., and Heaman, L.M., 2014, Filling in the juvenile magmatic gap: Evidence for uninterrupted Paleoproterozoic plate tectonics: Earth and Planetary Science Letters, v. 388, p. 123-133, https://doi.org/10.1016/j.epsl.2013.11.04

Paton, C., Hellstrom, J., Paul, B., Woodhead, J., and Hergt, J., 2011, Iolite: Freeware for the visualisation and processing of mass spectrometric data: Journal of Analytical Atomic Spectrometry, v. 26, p. 2508-2518, https://doi.org/10.1039/ c1ja10172b.

Pehrsson, S.J., Eglington, B.M., Evans, D.A.D., Huston, D., and Reddy, S.M., 2015, Metallogeny and its link to orogenic style during the Nuna supercontinent cycle, in Li, Z.X., Evans, D.A.D., and Murphy, J.B., eds., Supercontinent Cycles Through Earth History: Geological Society, London, Special Publications, v. 424, p. 83-94, https://doi.org/10.1144/SP424.5.

Perreault, S., and Hynes, A., 1990, Tectonic evolution of the Kuujjuaq terrane, New Québec Orogen: Geoscience Canada, v. 17, p. 238-240.

Petrus, J.A., and Kamber, B.S., 2012, VizualAge: A novel approach to laser ablation ICP-MS U-Pb geochronology data reduction: Geostandards and Geoanalytical Research, v. 36, p. 247-270, https://doi.org/10.1111/j.1751908X.2012.00158.x.

Poirier, G., Perreault, S., and Hynes, A., 1990, Nature of the eastern boundary of the Labrador Trough near Kuujjuaq, Quebec, in Lewry, J.F., and Stauffer, M.R., eds., The Early Proterozoic Trans-Hudson Orogen: Geological Association of Canada, Special Paper 37, p. 397-411.

Rainbird, R.H., 2004, Some advances in the study of Proterozoic sedimentary basins of North America: Precambrian Research, v. 129, p. 199-201, https://doi.org/ 10.1016/i.precamres.2003.10.001.

Rayner, N., and Corrigan, D., 2004, Uranium-lead geochronological results from the Churchill River-southern Indian Lake transect, northern Manitoba: Geological Survey of Canada, Current Research 2004-F1, 14 p.

Rayner, N.M., Lafrance, I., Corrigan, D., and Charette, B., 2017, New U-Pb zircon ages of plutonic rocks from the Jeannin Lake area, Quebec: an evaluation of the Kuujjuaq domain and Rachel-Laporte Zone: Geological Survey of Canada, Current Research 2017-4, 14 p.

Ryan, B., Krogh, T.E., Heaman, L., Schärer, U., Philippe, S., and Oliver, G., 1991, On 
recent geochronological studies in the Nain Province, Churchill Province and Nain Plutonic Suite, north-central Labrador: Geological Survey, Newfoundland Department of Mines and Energy, Current research, Report 91-1, p. 257-261.

Sanborn-Barrie, M., 2016, Refining lithological and structural understanding of the southern Core Zone, northern Quebec and Labrador in support of mineral resource assessment: Geological Survey of Canada, Open File 7965, 39 p. https://doi.org/10.4095/297560.

Sanborn-Barrie, M., Rayner, N.M., and Lion, A., 2015, Report of activities for the 2015 bedrock component of the GEM Southern Core Zone activity, northern Quebec and Labrador: Geological Survey of Canada, Open File 7952, 18 p., https://doi.org/10.4095/297271.

Scott, D.J., and St-Onge, M.R., 1998, Paleoproterozoic assembly of northeast Laurentia revisited: a model based on southward extrapolation of Ungava-Baffin architecture, in Wardle, R.J., and Hall, J., eds., Eastern Canadian Shield OnshoreOffshore Transect (ECSOOT), Report of the 1998 Transect Meeting: The University of British Columbia, Lithoprobe Secretariat, Report 68, p. 134-147.

Scott, D.J., Stern, R.A., St-Onge, M.R., and McMullen, S.M., 2002, U-Pb geochronology of detrital zircons in metasedimentary rocks from southern Baffin Island: implications for the Paleoproterozoic tectonic evolution of Northeastern Laurentia: Canadian Journal of Earth Sciences, v. 39, p. 611-623, https://doi.org/10.1139/e01-093.

Simard, M., Lafrance, I., Hammouche, H., and Legouix, C., 2013, Géologie de la region de Kuujjuaq et de la Baie d'Ungava (SNRC 24J et 24K): Ministère des ressources naturelles, Québec, RG 2013-04, 62 p.

Soesoo, A., Bons, P.D., Gray, D.R., and Foster, D.A., 1997, Divergent double subduction: Tectonic and petrologic control: Geology, v. 25, p. 755-758, https://doi.org/10.1130/0091-7613(1997)025<0755:DDSTAP>2.3.CO;2.

Stacey, J.S., and Kramers, J.D., 1975, Approximation of terrestrial lead isotope evolution by a two-stage model: Earth and Planetary Science Letters, v. 26, p. 207 221, https://doi.org/10.1016/0012-821X(75)90088-6.

Stauffer, M.R., 1984, Manikewan: An early proterozoic ocean in central Canada, its igneous history and orogenic closure: Precambrian Research, v. 25, p. 257-281, https://doi.org/10.1016/0301-9268(84)90036-6.

Stern, R.A., 1997, The GSC Sensitive High Resolution Ion Microprobe (SHRIMP): analytical techniques of zircon $\mathrm{U}-\mathrm{Th}-\mathrm{Pb}$ age determinations and performance evaluation: Geological Survey of Canada, Current Research 1997-F, p. 1-31, https://doi.org/10.4095/209089.

Stern, R.A., and Amelin, Y., 2003, Assessment of errors in SIMS zircon U-Pb geochronology using a natural zircon standard and NIST SRM 610 glass: Chemical Geology, v. 197, p. 111-142, https://doi.org/10.1016/S00092541(02)00320-0.

St-Onge, M.R., Scott, D.J., and Lucas, S.B., 2000, Early partitioning of Quebec: Microcontinent formation in the Paleoproterozoic: Geology, v. 28, p. 323-326, https://doi.org/10.1130/0091-7613(2000)28<323:EPOQMF>2.0.CO;2.

St-Onge, M.R., Searle, M.P., and Wodicka, N., 2006, Trans-Hudson Orogen of North America and Himalaya-Karakoram-Tibetan Orogen of Asia: Structura and thermal characteristics of the lower and upper plates: Tectonics, v. 25, TC4006, https://doi.org/10.1029/2005TC001907.

Taylor, F.C., 1979, Reconnaissance geology of part of the Precambrian Shield, northeastern Quebec, northern Labrador and Northwest Territories: Geological Survey of Canada, Memoir 393, 99 p., 19 maps, https://doi.org/10.4095/ 124930 .

van der Leeden, J., 1994, Géologie de la région du lac de la Hutte Sauvage (Territoire du Nouveau-Québec): Ministère de l'énergie et des Ressources, Québec; MB 94-32, 108 p., 2 plans.

van der Leeden, J., Bélanger, M., Danis, D., Girard, R., and Martelain, J., 1990, Lithotectonic domains in the high grade terrain east of the Labrador Trough (Quebec), in Lewry, J.F., and Stauffer, M.R., eds., The Early Proterozoic Trans-Hudson Orogen of North America: Geological Association of Canada, Special Paper 37, p. 371-386.

van Gool, J.A.M., Connelly, J.N., Marker, M., and Mengel, F.C., 2002, The Nagssugtoqidian Orogen of West Greenland: tectonic evolution and regional correlations from a West Greenland perspective: Canadian Journal of Earth Sciences, v. 39, p. 665-686, https://doi.org/10.1139/e02-027.

Verpaelst, P., Brisebois, D., Perreault, S., Sharma, K.N.M., and David, J., 2000, Géologie de la region de la rivière Koroc et d'une partie de la région de Hébron (24I et 14-L): Ministère des ressources Naturelles, Québec, RG 99-08, 62 p., 10 plans.

Wardle, R.J., and Van Kranendonk, M.J., 1996, The Palaeoproterozoic Southeastern Churchill Province of Labrador-Quebec, Canada: orogenic development as a consequence of oblique collision and indentation, in Brewer, T.S., ed., Precambrian Crustal Evolution in the North Atlantic Region: Geological Society, London, Special Publications, v. 112, p. 137-153, https://doi.org/10.1144/
GSL.SP.1996.112.01.08.

Wardle, R.J., Ryan, B., and Ermanovics, I., 1990, The Eastern Churchill Province, Torngat and New Quebec orogens: An overview: Geoscience Canada, v. 17, p. 217-222.

Wardle, R.J., James, D.T., Scott, D.J., and Hall, J., 2002, The southeastern Churchill Province: synthesis of a Paleoproterozoic transpressional orogeny: Canadian Journal of Earth Sciences, v. 39, p. 639-663, https://doi.org/10.1139/e02-004.

Whitmeyer, S.J., and Karlstrom, K.E., 2007, Tectonic model for the Proterozoic growth of North America: Geosphere, v. 3, p. 220-259, https://doi.org/ 10.1130/GES00055.1

Wodicka, N., Whalen, J.B., St-Onge, M.R., and Corrigan, D., 2010, Meta Incognita microcontinent revisited: insights from $\mathrm{U}-\mathrm{Pb}$ geochronology and $\mathrm{Nd}$ isotopes (Abstract): GeoCanada 2010, Calgary, Abstract 982-GC2010.

\section{Received February 2018 Accepted as revised March 2018}

*For access to the Corrigan et al. (2018) supplementary data, Table S-1 SHRIMP U-Pb data and Table S-2 LA-ICP-MS U$\mathrm{Pb}$ data, please visit the GAC's open source GC Data Repository link Andrew Hynes Series: Tectonic Processes at: https://www.gac.ca/wp/?page_id=306. 